\title{
A Case Study of Stratospheric Ozone Transport to the Northern San Francisco Bay Area and Sacramento Valley during CABOTS 2016
}

\author{
JODIE CLARK AND SEN CHIAO \\ Center for Applied Atmospheric Research and Education, San Jose State University, San Jose, California
}

(Manuscript received 6 December 2018, in final form 21 October 2019)

\begin{abstract}
The California Baseline Ozone Transport Study (CABOTS) was a major air quality study that collected ozone measurements aloft between mid-May and mid-August of 2016. Aircraft measurements, ground-based lidar measurements, and balloon-borne ozonesondes collected precise upper-air ozone measurements across the central and Southern California valley. Utilizing daily ozonesonde data from Bodega Bay, California, and Modern-Era Retrospective Analysis for Research and Applications, version 2 (MERRA-2), reanalysis data for 25 July to 14 August 2016, three stratospheric intrusion events are identified over Northern California influencing air masses above Bodega Bay and Sacramento simultaneously. Calculated percent daily changes in afternoon ozonesonde observations indicate increasing ozone concentrations from the point of likely stratospheric air injection with the arrival of higher potential vorticity, confirmed by ensemble back trajectories. An analysis of the onsite surface monitoring ozone data indicates ozone increases in the observations for dates of plausible low-level stratospheric air influence. Further, a comparison of Bodega Bay surface ozone observations and 14 Sacramento Valley nonattainment zone surface sites show that the surface ozone observed at the higher-elevation surface sites in the lower Sierra Nevada foothills were positively correlated with elevated ozone captured by the ozonesondes within the lowest $0.5-1 \mathrm{~km}$. The strongest correlations observed $(\sim 0.61)$ were between elevated Bodega Bay ozonesonde data and the Placerville $(\sim 612 \mathrm{~m})$ afternoon surface ozone data, an indication that these regions separated by $200 \mathrm{~km}$ would be influence by the same ozone source. A comparison of daily changes in afternoon ozone show that the two locales often experience similar daily ozone increases or decreases. While this study leads to a basic quantification of stratospheric influence on surface ozone in the Sacramento nonattainment zone, a future campaign that examines ozone and winds aloft at both locales is suggested to improve the quantification of stratospheric ozone.
\end{abstract}

\section{Introduction}

Stratospheric intrusions (SI) transport ozone-rich stratospheric air to the lower troposphere, intermittently enhancing ozone $\left(\mathrm{O}_{3}\right)$ concentrations in the lower troposphere (e.g., Cooper et al. 2001; Stohl et al. 2003; Lin et al. 2012, 2015; Tarasick et al. 2019). The deep descent of stratospheric air has been defined as that which crosses the dynamical tropopause and travels to $700 \mathrm{hPa}$ pressure level within 5 days (Bourqui and Trépanier 2010). The photochemical lifetime of $\mathrm{O}_{3}$ in the free troposphere is about 22 days (Stevenson et al. 2006). Since the nonconservative processes known to transport stratospheric air to the troposphere are on the order of a few days, such as the turbulence caused by strong wind shear typically found in tropopause folds, stratospheric $\mathrm{O}_{3}\left(\right.$ strat $\left._{3}\right)$ can significantly influence the

Corresponding author: Sen Chiao, sen.chiao@sjsu.edu background $\mathrm{O}_{3}\left(\mathrm{bgO}_{3}\right)$ in the free troposphere uninfluenced by anthropogenic emissions and the surface $\mathrm{O}_{3}\left(\mathrm{sfcO}_{3}\right)$ concentration (Bourqui and Trépanier 2010). Nevertheless, the challenge is to identify and quantify the influence of strat $_{3}$ and to what extent strat $_{3}$ intrudes into the troposphere to influence the $\mathrm{sfcO}_{3}$ pollution above the health-based limit (e.g., Ding and Wang 2006; Hsu and Prather 2009; Langford et al. 2009).

For decades potential vorticity (PV) and layered structures in $\mathrm{O}_{3}$ profiles have been used to identify stratospheric air masses (e.g., Danielsen et al. 1987; Oltmans et al. 1996; Roelofs et al. 2003; Škerlak et al. 2014). When defining the height of the tropopause, it is well established that the sharp rise in $\mathrm{O}_{3}$ corresponds well with the strong rise in PV (Trickl et al. 2014). One cause of variability to the tropopause height is Rossby wave propagation and breaking, which can lead to a SI of air with high PV into the subtropical and midlatitude upper troposphere (e.g., Waugh 2005; Ryoo et al. 2008; 
Bourqui and Trépanier 2010). Bourqui and Trépanier (2010) further categorized three distinct phases of an SI as the transport of stratospheric air across the tropopause; the free descent with minimal tropospheric mixing; and the quasi-horizontal dispersion into the lower troposphere.

Prior studies have suggested that the west coast of North America is a hot spot not only for SI, but deep SI, allowing for mixing into the boundary layer (BL) (e.g., Wernli and Bourqui 2002; Lefohn et al. 2012; Lin et al. 2012; Škerlak et al. 2014; Ryoo et al. 2017). Of the mass fluxes that cross the tropopause above California, $10 \%$ continue to cross the $700 \mathrm{hPa}$ level and $5 \%$ cross the $800 \mathrm{hPa}$ level (Škerlak et al. 2014). Although it has been known that SI occur more frequently in the Northern Hemisphere $(\mathrm{NH})$ winter and early spring due to the position of the jet streams, the strat $\mathrm{O}_{3}$ intrusion through deep SI instances occur above California in each season, and have been noted to reach the planetary BL similarly (Škerlak et al. 2014). Lin et al. (2012) found suggestions of strong $\mathrm{stratO}_{3}$ in the Sierra Nevada range. They suggest more measurements be recorded at these rural sites to gain insight into the influence of strat $\mathrm{O}_{3}$ on $\mathrm{sfcO}_{3}$ in the local urban area through a greater understanding of strat $\mathrm{O}_{3}$ influence on the $\mathrm{bgO}_{3}$ concentrations within the region.

From the air quality standards perspective, it is essential to investigate the quantitative relationship between deep SI and $\mathrm{sfcO}_{3}$ concentrations. Without convective processes or strong wind shear, the mixing of the intruded stratospheric air into tropospheric air would be a very slow process, possibly remaining stratospheric in nature for 1-2 weeks (Trickl et al. 2014). The downward transport of injected strat $\mathrm{O}_{3}$ from the lower troposphere to the surface could be further aided by wave activity, turbulence, or shear created by downslope winds. For instance, Langford et al. (2009) found that during the springtime in the metropolitan area of Denver, Colorado, SI brought extremely dry, $\mathrm{O}_{3}$-rich air to the surface sites that well exceeds the National Ambient Air Quality Standard (NAAQS). Yet evidence of the SI passed after just a few hours, demonstrating that the commonly performed weekly sampling of tropospheric $\mathrm{O}_{3}$ does not provide adequate data (Langford et al. 2009).

Quantifying the actual amount of strat $\mathrm{O}_{3}$ that contributes to tropospheric $\mathrm{O}_{3}$ remains a topic of interest. The layered structures found in vertical $\mathrm{O}_{3}$ profiles measured by ozonesondes is not reproduced well in many global and regional tropospheric chemical transport models (Roelofs et al. 2003; Lin et al. 2012). The models struggle further with deciphering the impacts of strat $\mathrm{O}_{3}$ influence on the $\mathrm{sfcO}_{3}$ observations (Lin et al. 2012). To capture the full impact of $\mathrm{SI}$ on $\mathrm{bgO}_{3}$ and $\mathrm{sfcO}_{3}$ conditions, daily measurements would be beneficial to the atmospheric chemistry and air quality communities and would contribute to strengthening model accuracy of forecasted $\mathrm{O}_{3}$ predictions.

Using the daily upper-air $\mathrm{O}_{3}$ measurements collected during the California Baseline Ozone Transport Study (CABOTS) 2016, this research aims to investigate SI that occurred over Northern California in relation to $\mathrm{sfcO}_{3}$ over the Sacramento area. Liu et al. (2009) found that the correlation strength between ozonesonde measurements decreased by a factor of $e$ in the stratosphere over distances of $1000-2000 \mathrm{~km}$ and in the troposphere over distances of 500-1000 km. Oltmans et al. (2008) found the observed air entering from the Pacific in the lower troposphere $(1-5 \mathrm{~km})$ above the marine $\mathrm{BL}$ provides a good picture of the $\mathrm{bgO}_{3}$ content. Therefore, coastal ozonesonde measurements would give a good indication of elevated $\mathrm{O}_{3}$ values $100-200 \mathrm{~km}$ eastward elevated above the Sacramento nonattainment zone.

Using high temporal density upper-air $\mathrm{O}_{3}$ measurements, the spatial and temporal characteristics of SI induced $\mathrm{sfCO}_{3}$ variability will be revealed. The primary objective of this study is to advance our understanding of stratO $_{3}$ influence during the passage of a SI over Northern California and aims to show the vertical descent of strat $_{3}$ to the surface is plausible following the passage of an SI into the middle troposphere. This study is unique to tell the tale of the vertical daily variability in $\mathrm{O}_{3}$ concentrations entering the central California coast by calculating the daily percent changes in $\mathrm{O}_{3}$ for a continuous 21 days of ozonesonde measurements, recognizing trends with time of increasing $\mathrm{O}_{3}$ concentrations following from the region of stratospheric air intrusion toward the surface. A secondary objective of this study is to discover a correlation between the strat $\mathrm{O}_{3}$ influencing $\mathrm{BL} \mathrm{O}_{3}$ at the North Bay area coastal region with the $\mathrm{sfcO}_{3}$ pollution observed in the Sacramento nonattainment zone and the lower Sierra Nevada foothills to quantify stratO $\mathrm{O}_{3}$ contributing to nonattainment.

Section 2 depicts the datasets utilized. In section 3, the SI events for analysis are defined. Section 4a confirms the SI events with HYSPLIT back trajectories and ozonesonde analysis. The trekking of strat $\mathrm{O}_{3}$ with time and surface ozone correlation results and discussion wrap up section 4 . Section 5 states the conclusions of the study and the ideas for further improvement. This study is largely based on the thesis research of Clark (2018), which is repeated in this paper with permission.

\section{Data collection}

\section{a. Ozonesonde measurements}

It is suggested by Lin et al. (2015) that weekly ozonesonde measurements at Trinidad Head, California, 


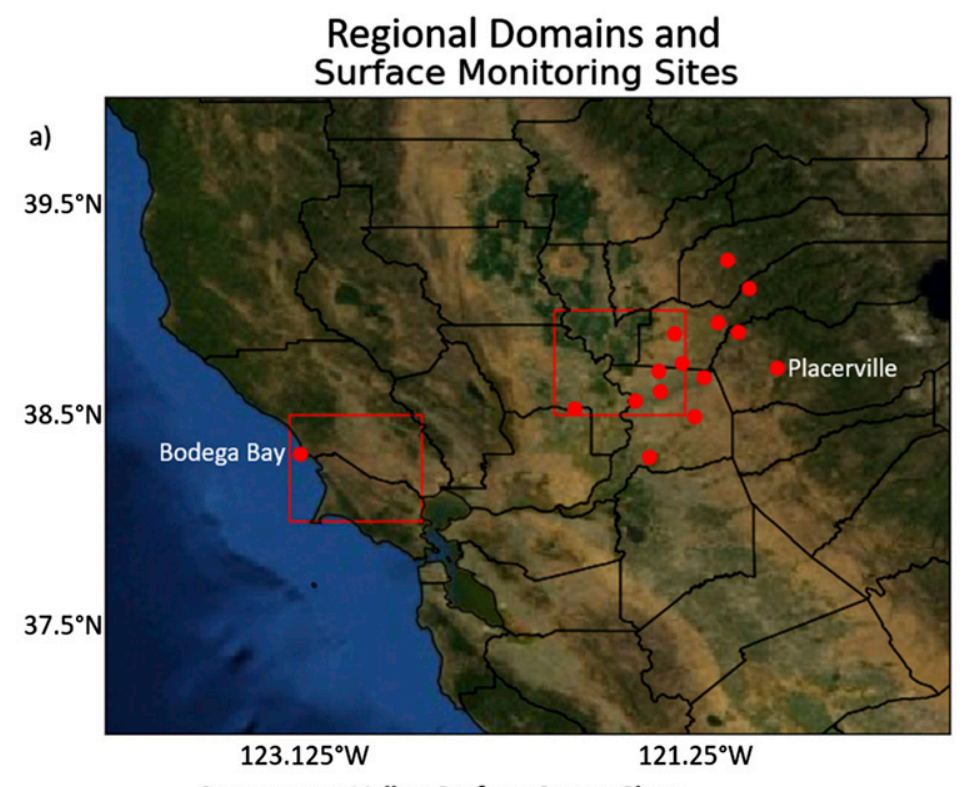

Sacramento Valley Surface Ozone Sites

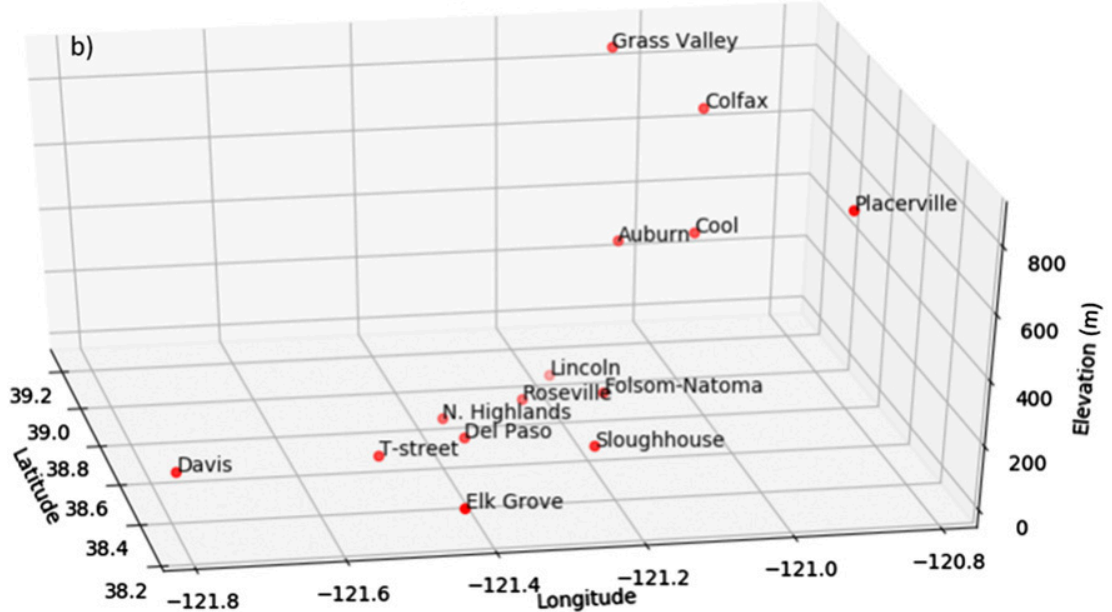

FIG. 1. (a) Location of the 15 surface ozone monitoring stations across Northern California and the Bodega Bay ozonesonde launch site. (b) 3D layout of the Sacramento surface stations with location names.

and Boulder, Colorado, are inadequate to capture the actual temporal variability of mean midtropospheric $\mathrm{O}_{3}$ in spring. The near-daily ozonesondes launched from Bodega Bay, California, contribute to the CABOTS campaign objective of bringing insight to the vertical daily variability of $\mathrm{bgO}_{3}$ as it enters the West Coast, which would include those variations of $\mathrm{bgO}_{3}$ due to SI contributing to this study's primary objective. As the shallow nocturnal BL heights grow to daytime heights, the higher $\mathrm{O}_{3}$ concentrations aloft begin to mix down in the elevated daytime BL. This, along with the daytime photochemical production of $\mathrm{O}_{3}$, leads to maximum $\mathrm{sfcO}_{3}$ concentrations in the afternoon (Parrish et al.2010). Therefore, the Bodega Bay ozonesondes were released at 2100 UTC (1400 local time) from $38.31869^{\circ} \mathrm{N}, 123.07197^{\circ} \mathrm{W}$ at an elevation of $12 \mathrm{~m}$ above sea level, and $200 \mathrm{~m}$ directly east from the coastline. Prior to this study, vertical $\mathrm{O}_{3}$ data had not been collected along the central coast of California making the CABOTS data a valuable new dataset.

A total of 86 near-daily ozonesondes were launched by the SJSU launch team at Bodega Bay, collecting finescale vertical $\mathrm{O}_{3}$ data throughout the troposphere and into the lower stratosphere. The ozonesonde launch site is shown in Fig. 1a. A time-height cross section plot, as shown in Fig. 2a, depicts the 100-m vertically averaged $\mathrm{O}_{3}$ concentrations measured during the entire field study, late May to early August 2016. The frequent occurrence of high $\mathrm{O}_{3}$ concentrations in the upper 

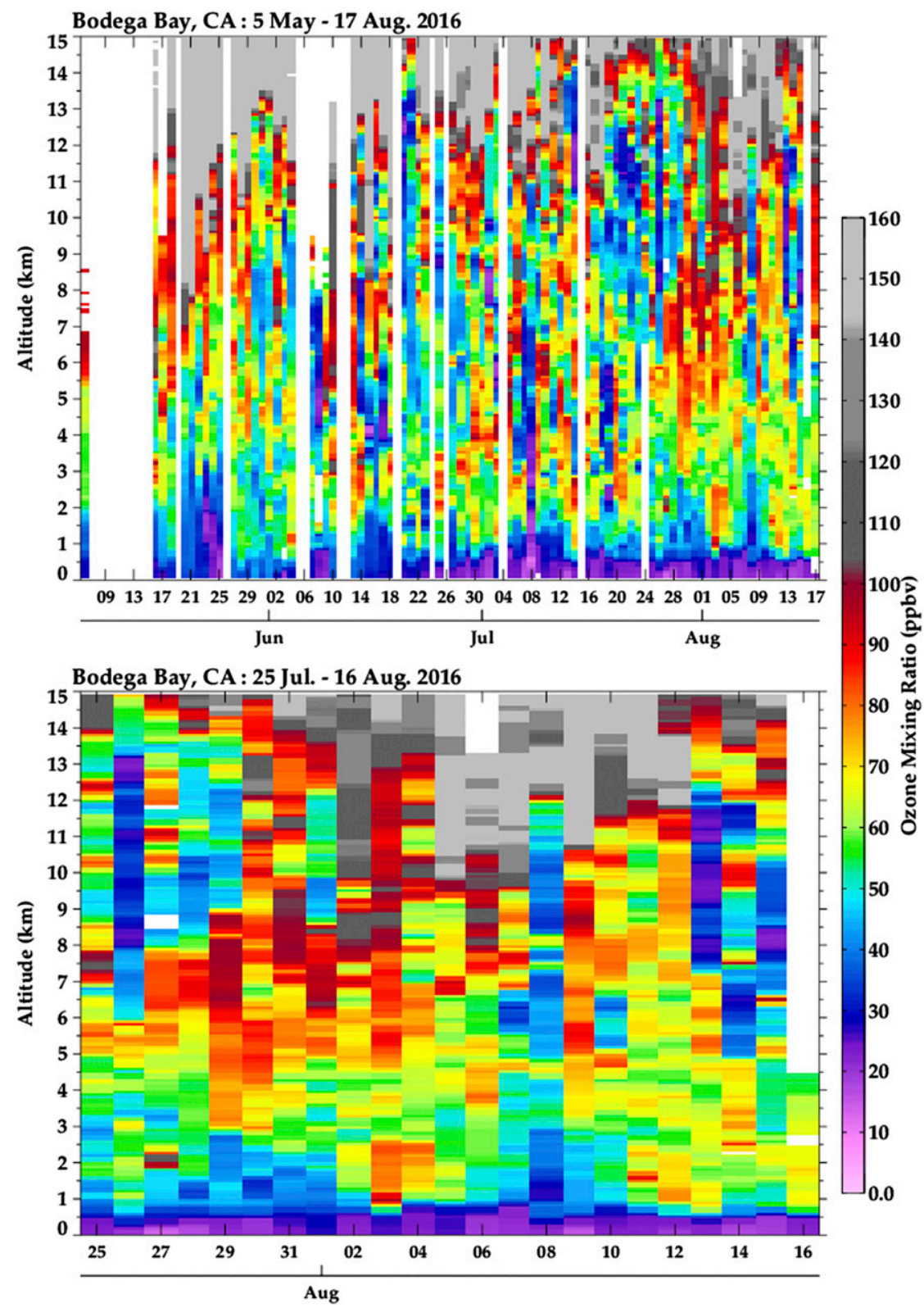

FIG. 2. Bodega Bay near-daily ozonesonde observations. Color scale concentrations from 0 to 160 ppb. (a) all CABOTS data, 2016. (b) 25 Jul-16 Aug 2016.

troposphere was clearly recognizable within the data. On occasion, relatively high $\mathrm{O}_{3}$ concentrations extend down from the tropopause toward the lower troposphere, impacting below $4 \mathrm{~km}$ (Fig. 2a).

In the lower levels, the observed $\mathrm{O}_{3}$ values would include $\mathrm{O}_{3}$ mixing upward from the surface, long-range transport, and mixing from upper-level layers due to SI. In the lower $2 \mathrm{~km}$, multiple occurrences of $\mathrm{O}_{3}$ concentrations greater than $70 \mathrm{ppb}$ were observed (Fig. 2a). Figure $2 b$ displays the $\mathrm{O}_{3}$ measurements collected during the period of 25 July through 16 August 2016. During this defined case study period, the air quality index for $\mathrm{sfcO}_{3}$ pollution in the Sacramento nonattainment zone was classified as moderate to unhealthy. Successive accurate ozonesonde launches were performed collecting quality daily observations of coastal $\mathrm{O}_{3}$ aloft throughout a $15 \mathrm{~km}$ vertical column, except for 16 August where complications allowed for data up to $5 \mathrm{~km}$.

\section{b. MERRA-2 reanalysis}

MERRA-2 reanalysis data have been recognized as a valuable dataset and tool in the use of identifying SIs 
(Knowland et al. 2017). Therefore, this study utilizes this global dataset for analysis of $250 \mathrm{hPa}$ geopotential height and wind speed over a domain that covers the eastern North Pacific Ocean and most of North America, and for a vertical cross-section analysis of PV and wind speed to show the occurrence of the SI events over Northern California during a period of 25 July-13 August 2016. The MERRA-2 model dataset is composed of 72 hybrid sigma-pressure levels with a resolution of $0.5^{\circ}$ latitude $\times 0.625^{\circ}$ longitude, and a 3-hourly time stamp.

\section{c. Surface monitoring stations}

Data from $15 \mathrm{sfcO}_{3}$ monitoring stations were used for analysis of the unhealthy air conditions in the Sacramento nonattainment zone (Table 1). $\mathrm{SfcO}_{3}$ data were provided by the California Air Resources Board (CARB) and included the hourly average $\mathrm{sfcO}_{3}$ values observed during the period of the CABOTS project. Observations from 14 surface sites were used within this case study (Fig. 1b). The $\mathrm{sfcO}_{3}$ data for Bodega Bay were provided by the Bay Area Air Quality Management District (BAAQMD). This dataset included $\mathrm{sfcO}_{3}$ values observed for every minute, which were averaged to hourly $\mathrm{O}_{3}$ data for 25 July-17 August 2016.

\section{Defining three SI cases}

In general, the dynamic tropopause is defined when $\mathrm{PV}$ is equal to $2 \mathrm{PVU}$ (1 PVU $=10^{-6} \mathrm{~m}^{2} \mathrm{~s}^{-1} \mathrm{~K} \mathrm{~kg}^{-1}$ ), but accepted values range from 1 to $5 \mathrm{PVU}$ with the lowest values indicative of a deep SI that captures the streamers associated with the fold (Cox et al. 1997). Large PV values in the troposphere are regarded to be linked to the stratosphere, and a value of 5.0 PVU would mark a definite boundary between stratospheric and tropospheric air. In this study, a value of 1.5 PVU was used to indicate the height of the tropopause near folds, and a value of 1.0 PVU indicates the deeper intrusion of stratospheric air below the tropopause into the troposphere.

Vertical cross sections were performed to analyze the placement of the upper-level jet stream and the arrival of the high PV values to the Bodega Bay (BBY) vertical column of air. Figures 3-5 show the PV and wind speed values along three different cross sections: 1 ) a vertical cross section along the U.S. West Coast from a point in the Gulf of Alaska $\left(50.0^{\circ} \mathrm{N}, 132.0^{\circ} \mathrm{W}\right)$ crossing through Bodega Bay and to a point off the southern west coast of Baja California $\left.\left(25.0^{\circ} \mathrm{N}, 116.0^{\circ} \mathrm{W}\right) ; 2\right)$ a vertical cross section from southern British Colombia $\left(50.0^{\circ} \mathrm{N}\right.$, $118.0^{\circ} \mathrm{W}$ ) to the southeast along the Cascade Mountain Range, crossing through BBY and into the Pacific Ocean $\left(25.0^{\circ} \mathrm{N}, 127.0^{\circ} \mathrm{W}\right)$; and 3$)$ a longitudinal vertical cross section starting in the Pacific Ocean off the California west
TABLE 1. Surface ozone monitoring sites locations.

\begin{tabular}{lccc}
\hline \hline \multicolumn{1}{c}{ Name } & $\begin{array}{c}\text { Latitude } \\
\left({ }^{\circ} \mathrm{N}\right)\end{array}$ & $\begin{array}{c}\text { Longitude } \\
\left({ }^{\circ} \mathrm{W}\right)\end{array}$ & $\begin{array}{c}\text { Elevation } \\
\text { MSL }(\mathrm{m})\end{array}$ \\
\hline Grass Valley (GV) & 39.23352 & 121.05567 & 865 \\
Colfax (Cfx) & 39.09979 & 120.95391 & 738 \\
Placerville (Pvle) & 38.72528 & 120.82192 & 612 \\
Cool (Cl) & 38.89094 & 121.00337 & 473 \\
Auburn (Ab) & 38.93568 & 121.09959 & 434 \\
Folsom-Natoma (FN) & 38.68329 & 121.16444 & 108 \\
Roseville (Rvle) & 38.74643 & 121.26498 & 60 \\
Sloughhouse (Sh) & 38.49444 & 121.21115 & 59 \\
Lincoln (Ln) & 38.88559 & 121.30199 & 47 \\
North Highlands (NH) & 38.71209 & 121.38108 & 33 \\
Del Paso (DP) & 38.61374 & 121.36801 & 30 \\
Davis (Dvs) & 38.53455 & 121.77340 & 19 \\
T-Street (TSt) & 38.56844 & 121.49311 & 15 \\
Bodega Bay (BBY) & 38.31869 & 123.07197 & 12 \\
Elk Grove (EG) & 38.30256 & 121.42083 & 7 \\
\hline
\end{tabular}

coast $\left(35.9^{\circ} \mathrm{N}, 134.0^{\circ} \mathrm{W}\right)$ to a point almost directly westward in the Pinyon Creek Canyon of Utah $\left(40.0^{\circ} \mathrm{N}\right.$, $112.0^{\circ} \mathrm{W}$ ) allowing the data to pass through BBY and Placerville, California. In the upper-left-hand corner, the figures include the $250 \mathrm{hPa}$ geopotential height and wind speed to link the regions of higher PV with the known signatures of tropopause folding, the upper-level jet stream and jet streaks, the synoptic scale features of upper-level fronts, and the low pressure systems across the domain (Lin et al. 2012; Škerlak et al. 2014). Since ozonesonde data were only collected for 2100 UTC, the MERRA-2 data shown are for the day of the SI event into the BBY region, and the proceeding and following days at this time stamp.

As of 25 July 2016, the $250 \mathrm{hPa}$ geopotential heights show the presence of a developed upper-level closed low over southern Alaska with a broad trough across the Gulf of Alaska. To the south was an upper-level cutoff low that elongated and separated toward the east of Hawaii, while a small upper-level closed low perturbance lifts into the jet stream. A broad upper-level ridge of high pressure extended from the Pacific Ocean, across the lower United States and Mexico; engulfed was an upper-level cutoff low centered between the southern tip of Baja California and the Hawaiian Islands on a westward track. The jet stream propagated across the Pacific entering the Pacific Northwest and Northern California, zonally across the upper-level high pressure ridge.

By 26 July 2016 at 2100 UTC, the upper-level closed low over Alaska has deepened. Only a small trace of the upper-level cutoff low remained to the north of Hawaii (Fig. 3). The broad upper-level ridge of high pressure that extended from the desert southwest builds slightly at the U.S. West Coast and remained over the eastern Pacific and southern United States. The jet stream 


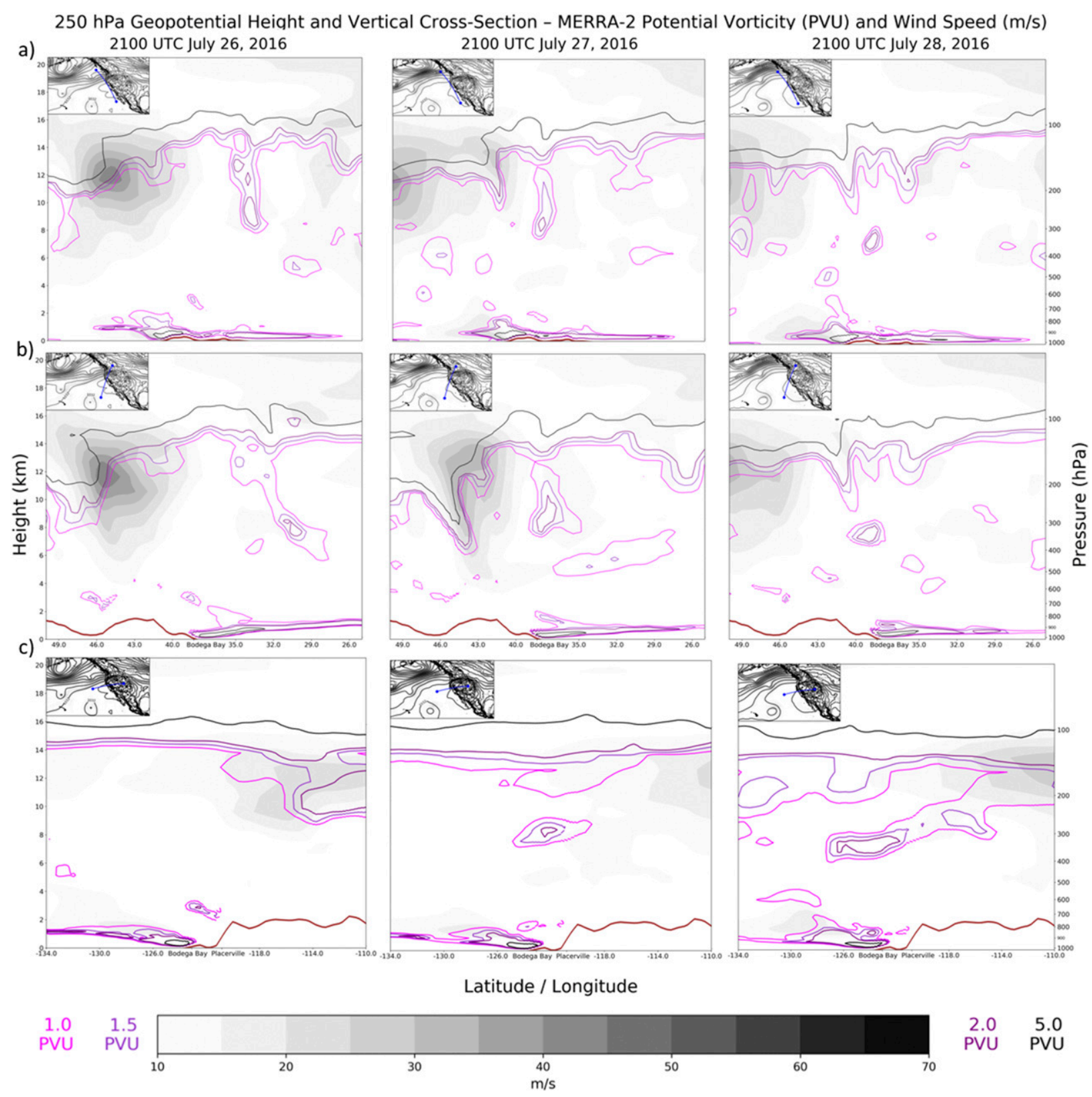

FIG. 3. MERRA-2 2100 UTC PV and wind speed reanalysis data along three vertical cross sections for (left) 26 Jul, (middle) 27 Jul, and (right) $28 \mathrm{Jul} 2016$, color plotted open contours for values of 1.0, 1.5, 2.0, and 5.0 PVU, gray filled contours of wind speed; and $250 \mathrm{hPa}$ geopotential height contours and wind speed in the upper-left corners. (a) NW to SE, (b) SW to NE, and (c) W to E.

remained in a similar location with a zonal entrance across the Pacific Northwest. Some embedded shortwave troughs from the once-strong embedded upperlevel cutoff low to the north of Hawaii progressed upstream, one remained just offshore of Northern California (Fig. 3). The jet-stream pushes farther northward as the high pressure ridge builds over the coast; the southern cutoff low continued the westward track toward Hawaii.
The first SI (SI 1) of interest into the elevated air above Northern California, recognized in the ozonesonde data, began on the afternoon of 27 July 2016 and remained present into 28 July 2016 . Figure $3 b$ indicates that an intrusion of stratospheric air occurred with the southern westward-tracked upper-level cutoff low, and a streamer from the low progressed to the northeast and influenced the air mass elevated above BBY as the upper-level ridge built over the four corners 
$250 \mathrm{hPa}$ Geopotential Height and Vertical Cross-Section - MERRA-2 Potential Vorticity (PVU) and Wind Speed (m/s)

a)

b)
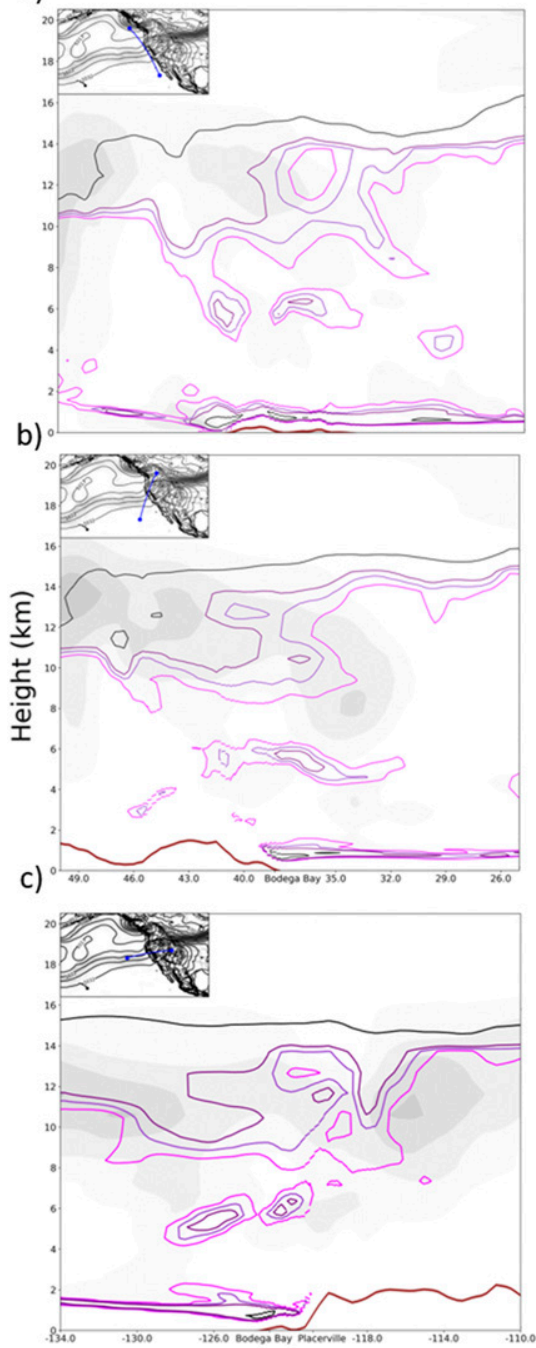

2100 UTC Aug 05, 2016
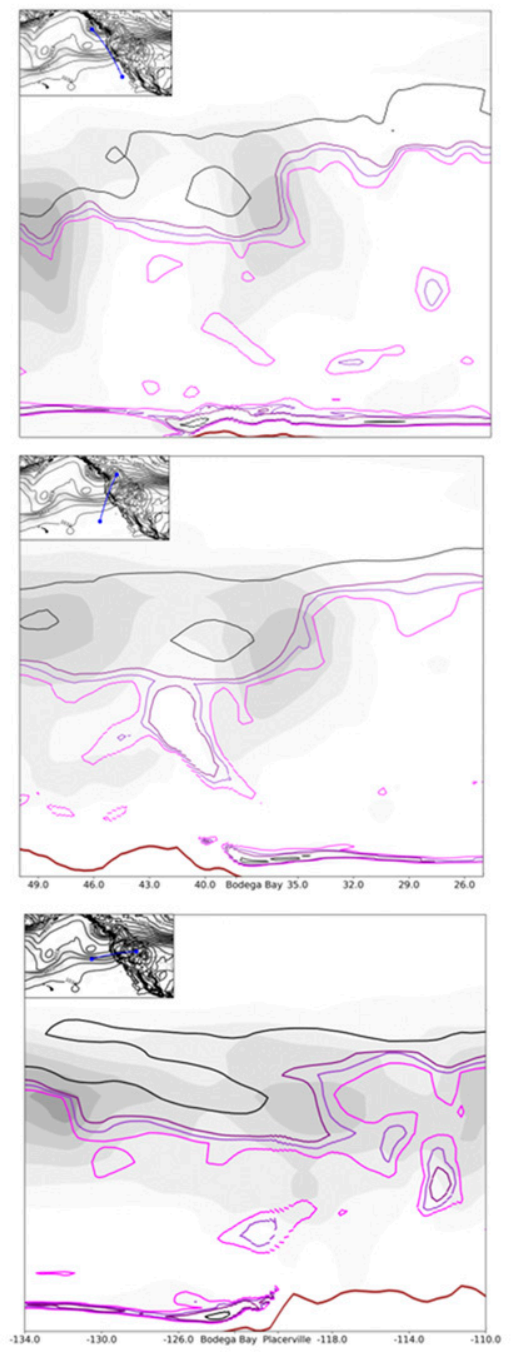

Latitude / Longitude
2100 UTC Aug 06, 2016
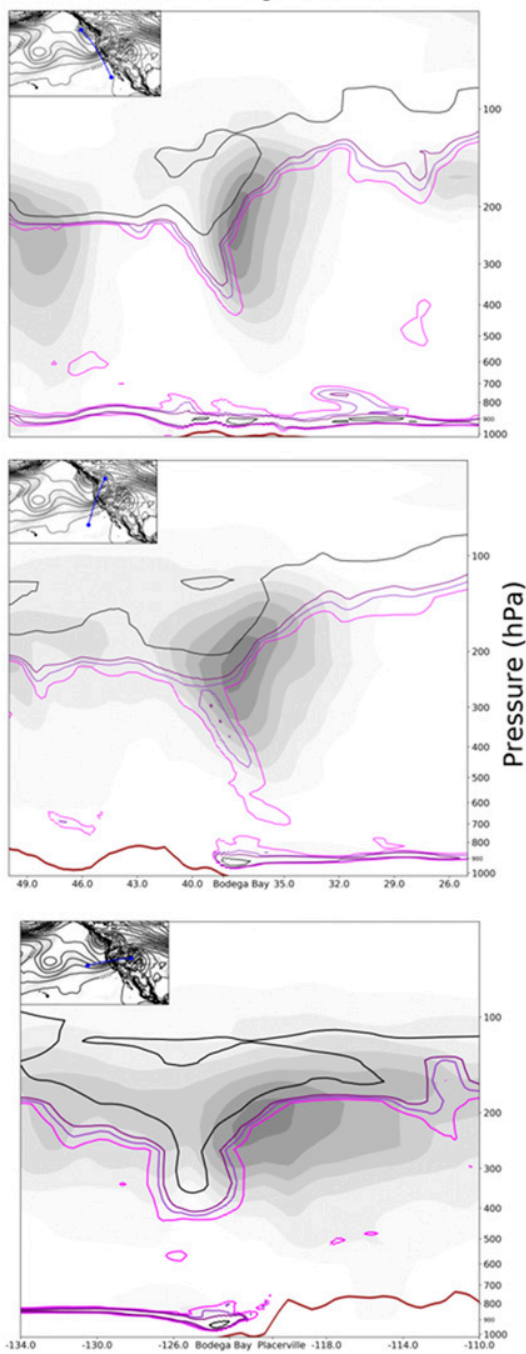

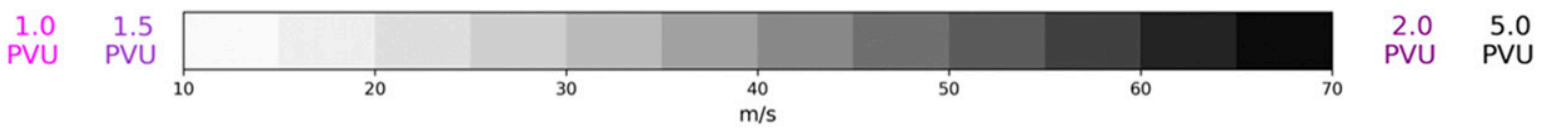

FIG. 4. MERRA-2 2100 UTC PV and wind speed reanalysis data along three vertical cross sections on (left 4 Aug, (middle) 5 Aug, and (right) 6 Aug 2016, color plotted open contours for values of 1.0, 1.5, 2.0, and 5.0 PVU, gray filled contours of wind speed; and 250 hPa geopotential height contours and wind speed in the upper-left corners. (a) NW to SE, (b) SW to NE, and (c) W to E.

(Center for Atmospheric Research and Education 2016). The high PV air mass progressed westerly across the state of California and through, influencing the air mass elevated above BBY and the Sacramento nonattainment zone represented by Placerville into the hours of 28 July 2016 as high PV separates from the tropopause and an enclosed region of high $\mathrm{PV}$ remained at about $8 \mathrm{~km}$ (Fig. 3c). The intrusion of stratospheric air into the $7-14 \mathrm{~km}$ vertical column elevated above BBY and Placerville passed through by 29 July 2016.
Over the course of the next week, the upper-level ridge of high pressure to the south weakened, multiple regions of high and low pressure circulated around the open Pacific, and the jet stream diverged into two weaker jets: one across the Pacific Ocean and one to the north. The southern upper-level cutoff low began a northwestward trek to the north of Hawaii and toward the southern westerly jet stream across the open Pacific. Along the jet stream to the north, three upper-level closed lows dropped into 
$250 \mathrm{hPa}$ Geopotential Height and Vertical Cross-Section - MERRA-2 Potential Vorticity (PVU) and Wind Speed (m/s)

a)

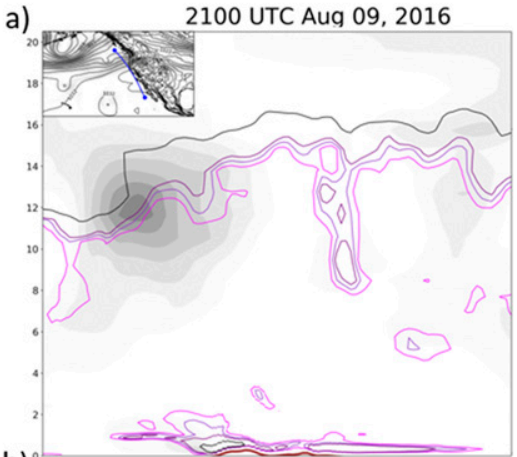

b)

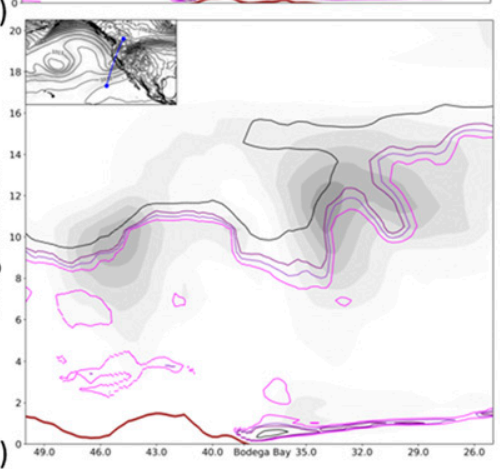

c)

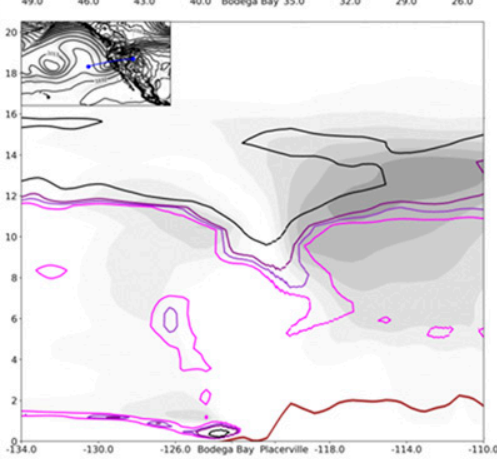

2100 UTC Aug 10, 2016
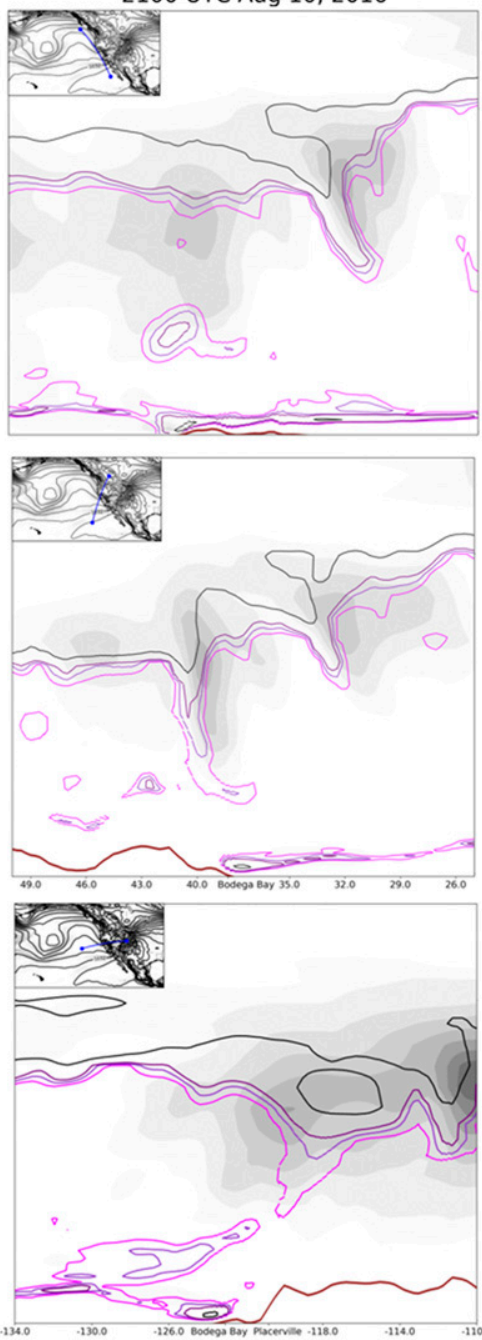

2100 UTC Aug 11, 2016
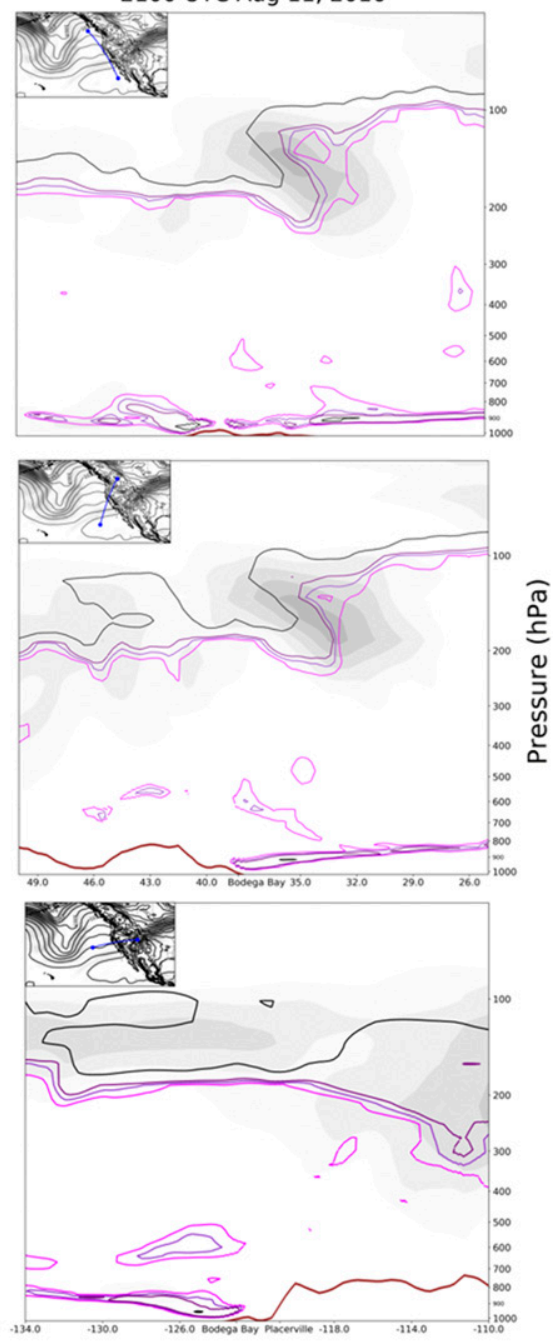

Latitude / Longitude

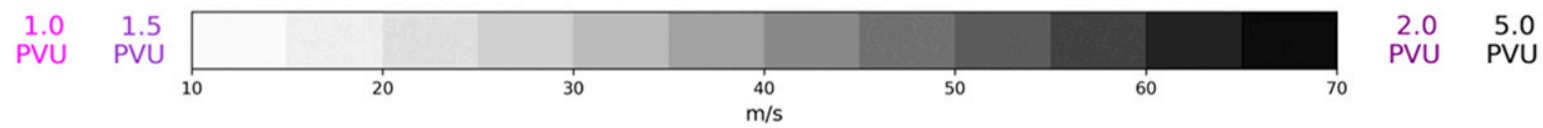

FIG. 5. MERRA-2 2100 UTC PV and wind speed reanalysis data along three vertical cross sections on (left) 9 Aug, (middle) 10 Aug, and (right) 11 Aug 2016, color plotted open contours for values of 1.0, 1.5, 2.0, and 5.0 PVU, gray filled contours of wind speed; and 250 hPa geopotential height contours and wind speed in the upper-left corners. (a) NW to SE, (b) SW to NE, and (c) W to E.

Alaska and progressed westward across the Gulf and into southern Canada.

By 2100 UTC 4 August 2016, as the upper-level high pressure ridge at the West Coast weakened. The southern jet stream crossing into the United States, which extended from the upper-level cutoff low across the Pacific, had broadened from Southern California to northern Oregon from the southwest (Fig. 4). The upper-level cutoff low to the north of Hawaii now exhibited a positive tilt as a powerful shortwave trough elongated the trough axis to the west. As higher pressure built in the Gulf of Alaska, the third upper-level closed low had progressed along the coast of British Columbia and approached northern Washington, also influenced with a shortwave trough. Figure 4 indicates the height of the 1.5 PVU tropopause over California had lowered to near $9 \mathrm{~km}$ while the 2.0 PVU remained elevated as high as $14 \mathrm{~km}$ above BBY and Placerville. 
As shown in Fig. 4, multiple regions of 1.0-2.0 PVU extended into the midtroposphere at $8-4 \mathrm{~km}$ and trekked into the region from the west with short-wave troughs along the jet stream. The second SI (SI 2) of interest recognized in the ozonesonde data occurred with the lowering of the 2.0 and 5.0 PVU line elevated above the BBY region early on 5 August 2016. The closed upper-level low to the north digs slightly deeper along the coast of British Columbia and the circulation separated from the flow of the upper-level cutoff low to the north of Hawaii. The embedded short-wave trough began to swing through the upper-level closed low, and the trough deepened. The jet stream strengthens and traverses across the middle of California in a northeasterly direction, crossing above the North Bay area, Sacramento, and Tahoe. By 2100 UTC 6 August 2016 the center of the closed low pressure was above northern Washington and trekking southward, the embedded short-wave trough swung into the center of the trough axis just off the West Coast (Fig. 4c), with an extension of the 1.0 PV line to as low as $700 \mathrm{hPa}$. The upper-level cutoff low remained circulating over the open Pacific Ocean to the north of Hawaii, with a strong jet forming to its north along the Aleutian Islands as a center of low pressure was forming and a small high pressure ridge was present in the Gulf of Alaska.

As the jet progressed over the upper-level ridge of high pressure in the Gulf of Alaska, the flow of the upper-level cutoff low and closed low was in unison once more. Over the next $24 \mathrm{~h}$ another short-wave trough progressed through, once again strengthening and separating the flow of the upper-level lows. By 2100 UTC 8 August 2016, the center of the upper-level closed low has moved southward above western Washington and Oregon, with an embedded short-wave trough forming a strong upper-level frontal boundary perfect for tropopause folding. The jet core was elevated at $10-12 \mathrm{~km}$ above the region of interest. Offshore to the northwest of the jet core, the 5.0 PVU line extended down to $10 \mathrm{~km}$ in a southeasterly direction, and the 1.0 PVU extended toward $5 \mathrm{~km}$ in a narrow strip (Fig. 5a). To the northeast the 5.0 PVU line extended down to $8 \mathrm{~km}$ though the center of closed low, with 1.0 PVU extended toward $2.0 \mathrm{~km}$ through the center and across the frontal boundary (Fig. 5b).

By 9 August 2016, the upper-level ridge of high pressure remained in the Gulf of Alaska and the strong upper-level jet stream traversed along hugging the Gulf of Alaska. Figure 5 shows the center of the upper-level closed low progressed to the east above Washington and Oregon and exhibited an elongated positive tilted trough, or upper-level front, extended off the west of Southern California. The large upper-level front passed through BBY in the late morning hours of 9 August 2016; the third SI (SI 3) of interest recognized in the ozonesonde data. While the strong upper-level front passed though quickly, the closed low moves slowly to the east, squeezed as an upper-level high pressure ridge was present above the desert southwest and the southeast states. Figure 5 indicates that behind the front to the northwest, west, and even to the northeast of the upperlevel closed low, many 1.0 PVU and some 1.5 PVU air masses were present elevated between 8 and $2 \mathrm{~km}$. The front swings though, deepening the base of the trough to pass over Southern California. The higher values of PV stream in from the northwest around the jet core, and the 1.0-2.0 PVU lines extended into the midtroposphere. By 2100 UTC 9 August 2016 the 5.0 PVU line drops to near $10 \mathrm{~km}$ elevated above the width of California within the region of interest, and the 1.0 PVU line drops to near $7 \mathrm{~km}$ (Fig. 5).

By 2100 UTC 10 August 2016, the upper-level trough broadened over the western United States. The streamer of SI 3 extended from the tropopause above Nevada and Utah, across the region of interest, and out into the lower air mass elevated above the coastal ocean (Fig. 5c). The streamer remained present into the morning hours of 11 August 2016. The trough lifted by 2100 UTC 11 August 2016 and the ridge of high pressure progressed onshore over the western United States. The tail end of the streamer cut off from the tropopause and remained elevated $2-4 \mathrm{~km}$ above BBY, extended to the west-southwest over the coastal waters (Figs. 5b,c). The stratospheric air mass descended toward the surface over the next hours as the area was influenced by higher pressure (Center for Atmospheric Research and Education 2016).

During the defined time periods, the three SIs cross over and influence both the North Bay area and the Sacramento nonattainment zone (SAC). From the comparison of MERRA-2 PV longitudinal cross sections in Figs. 3c, 4c, and 5c, the same SI of interest were noted above BBY and SAC. These similarities to the elevated air masses define the regions as comparable, especially above $2 \mathrm{~km}$. Therefore, BBY ozonesonde measurements would give an indication of vertical $\mathrm{O}_{3}$ structure above SAC. It is important to note that the PV values in the lower $3 \mathrm{~km}$ are prominent offshore during all hours analyzed. While the diabatic heating effect can be a dominant factor to produce high $\mathrm{PV}$ if air is moist in the low levels of the troposphere $(<3 \mathrm{~km})$, this has shown to not be the case if a region also exhibits low specific humidity (Hoskins et al. 1985). From the Center for Atmospheric Research and Education (2016) the air of this region was quite dry during the period, especially above the marine layer. Inland, the high PV values appear at the surface generally between 0600 
and 1500 UTC in occurrence with the land-sea breeze circulation and other mesoscale complexes.

\section{Method and analysis}

\section{a. Confirming SIs with HYSPLIT and CABOTs data}

The NOAA HYSPLIT archive back-trajectory model was run to confirm the directionality of the air as it approached BBY followed along the path of the high PV air masses. The model simulations used the $0.5^{\circ}$ resolution GFS global model dataset with an isentropic vertical velocity calculation ensemble method to evaluate the air entering the elevated region above the BBY launch site located at $38.318^{\circ} \mathrm{N}, 123.071^{\circ} \mathrm{W}$. Produced from the HYSPLIT model (Stein et al. 2015), Figs. 6-8 confirm the air that entered the vertical column above BBY at 2100 UTC on the dates of 27 July, 5 August, and 9 August 2016 followed a similar 4-day path as the proposed high PV SI events defined in section 3: from the south and from the west; from the west, southwest, and northwest; from the strong low pressure system to the north.

The multiple elevations analyzed during the backtrajectory analysis (Figs. 6-8) link the arrival of high PV (Figs. 3-5) with the afternoon $\mathrm{O}_{3}$ increases calculated for the corresponding dates (Fig. 9). The daily variation of $\mathrm{O}_{3}$ by height was evaluated to visualize the influence and progression of the dry, $\mathrm{O}_{3}$-rich stratospheric air masses with time. Utilizing BBY ozonesonde observations, the daily percent changes in $\mathrm{O}_{3}$ were calculated for the $15 \mathrm{~km}$ vertical air column from one afternoon to the next for 25 July-14 August. Equation (1) shows the simple calculation for the daily $\mathrm{O}_{3}$ percent changes for each 100-m average $\mathrm{O}_{3}$ value:

$$
\Delta \mathrm{O}_{3} \%=\left[\frac{\left(\mathrm{O}_{3} \mathrm{ppb}_{f}-\mathrm{O}_{3} \mathrm{ppb}_{i}\right)}{\left|\mathrm{O}_{3} \mathrm{ppb}_{i}\right|}\right](100) \text {. }
$$

Figure 9 shows the daily percent changes in measured $\mathrm{BBY} \mathrm{O}_{3}$ for the period. Within the region of the tropopause $(10-12 \mathrm{~km})$ some of the largest daily percent changes in $\mathrm{O}_{3}$ occurred. The elevations are marked in Fig. 9 by a number and a letter indicating an intrusion of strat $_{3}$ into the region. The number indicates the SI case and the letter corresponds to the cross section that exhibited the high PV air masses (Figs. 3-5). The greatest change in $\mathrm{O}_{3}$ observed from SI 1 was an increase of $258 \%$ to $86 \mathrm{ppb}$ at $10.9 \mathrm{~km}$ on 27 July 2016 (Fig. 9a). At this elevation, the top-left image of Fig. 6 shows the back trajectories come from two distinct regions at very different paces. It is estimated about half the trajectories approach from the west near Hawaii along the jet stream, while the other half progresses slowing up from the south near northern Mexico with the building of high pressure. At $11 \mathrm{~km}$ on 5 August 2016, the observed $\mathrm{O}_{3}$ value was $198 \mathrm{ppb}$, a 236\% increase from the afternoon prior (Fig. 9b). The top-left image of Fig. 7 indicates that the air entering this region converges early above the open pacific then treks westward along the jet stream. The greatest of all the daily $\mathrm{O}_{3}$ percent changes for this study was observed at $11.1 \mathrm{~km}$ on 9 August, an increase of $\mathrm{O}_{3}$ by $415 \%$ from the afternoon prior to 169 ppb (Fig. 9b). The back trajectories of the top-left image in Fig. 8 indicate the air entering BBY at this elevation strongly follow the circulation of the low pressure system to the north.

Significant $\mathrm{O}_{3}$ increases were observed in the midtroposphere as well. At the height of 6-8 km, the MERRA$2 \mathrm{PV}$ cross section showed a cutoff of high PV beginning on 27 July 2016 (Fig. 3). The BBY ozonesonde captured daily $\mathrm{O}_{3}$ increases that ranged from $90 \%$ to $110 \%$, a near- $40-\mathrm{ppb}$ increase (Fig. 9a). Afternoon $\mathrm{O}_{3} \%$ increases of near $100 \%$ were observed near $7 \mathrm{~km}$ on 5 August 2016 (Fig. 9b) and an indication on 1.0 PVU was present (Fig. 4b). The $5 \mathrm{~km}$ ensemble back trajectories in the lower left of Fig. 7 indicate air reaching this elevation is approaching from many directions. Some of the air came from the north elevated above British Columbia on 2 August 2016 at the same time as an upper-level low progressed through the region described briefly in section 3 . This indicates the arrival of $\mathrm{sratO}_{3}$ into the region of interest. On 9 August increases in $\mathrm{O}_{3}$ occurred throughout most of the vertical column, the $1-7 \mathrm{~km}$ of up to $155 \%$ (Fig. 9b). A region of $1.0 \mathrm{PVU}$ was present in the $4-5 \mathrm{~km}$ vertical column of Fig. 5 .

\section{b. CABOTs data: Tracking SI influence with time}

As previously noted, SI 1 occurred with a relatively high tropopause height of $14 \mathrm{~km}$ (Fig. 3). The ozonesonde data captured the beginning of this event as an increase of observed $\mathrm{O}_{3}$ through a long vertical column between 6 and $14 \mathrm{~km}$ on 26-27 July 2016 (Fig. 9a). Smaller $\mathrm{O}_{3}$ increases were observed at the same altitudes on 28 July as the intrusion remained (Fig. 9a). While SI 1 was not likely the cause of any lower-level increases in $\mathrm{O}_{3}$, the progression of increasing $\mathrm{O}_{3}$ with time from SI 1 is examined in Fig. 9a. Three other possible low-level intrusion cases $(\mathrm{P})$ are marked in Fig. 9a. While it is likely that these low-level increases of $\mathrm{O}_{3}$ that appear to descend to the surface with time are linked with low pressure systems to the north, uncertainty remains, and the cases should be closer examined.

Figure $9 b$ follows the progression of the increasing $\mathrm{O}_{3}$ with time associated with SI 2 and SI 3. As each SI is associated with a lowering of the tropopause and an intrusion of stratospheric air into the midtroposphere, the progression of increasing $\mathrm{O}_{3}$ is tracked from multiple 

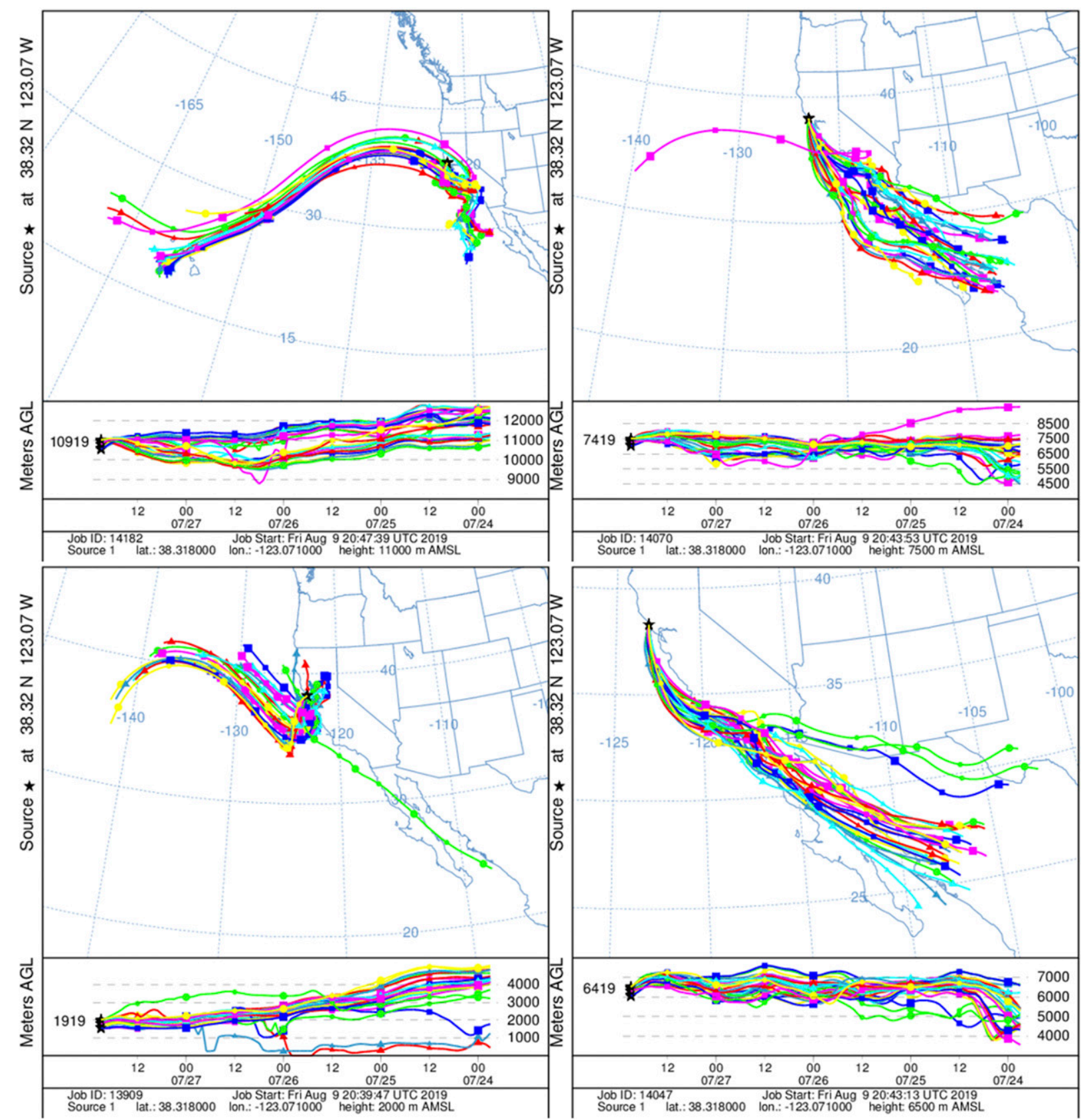

FIG. 6. NOAA HYSPLIT isentropic 96-h ensemble back trajectories for 2100 UTC 27 Jul 2016 at multiple elevations in the vertical column elevated above the BBY ozonesonde launch site.

altitudes. BBY ozonesonde percent change data captured increases in $\mathrm{O}_{3}$ from 4 to 5 August observed through the 7-14 km vertical column with the arrival of SI 2 (Fig. 9b). $\mathrm{SI} 3$ is discussed in greater detail as strat $\mathrm{O}_{3}$ likely influence the overnight $\mathrm{sfCO}_{3}$ concentrations.

On 9 August 2016, with the arrival of the strong upper-level front, increases in observed $\mathrm{O}_{3}$ occurred throughout most of the vertical column, excluding the upper and the lower one kilometer. Figure 8 shows that the air between 2 and $6 \mathrm{~km}$ follows the same path as the upper-level intrusion, but the increases in $\mathrm{O}_{3}$ observed in Fig. $9 \mathrm{~b}$ are not represented by high PV in the vertical cross sections of Fig. 5. The 4-5 km ensemble back trajectories for 9 August in Fig. 8 indicate that some of the air entering BBY had previously passed through BBY on 6 August at a higher elevation between 4 and $8 \mathrm{~km}$. Therefore, Fig. 9 indicates the decent of strat $\mathrm{O}_{3}$ with time from the ozonesonde observations of high PV on 

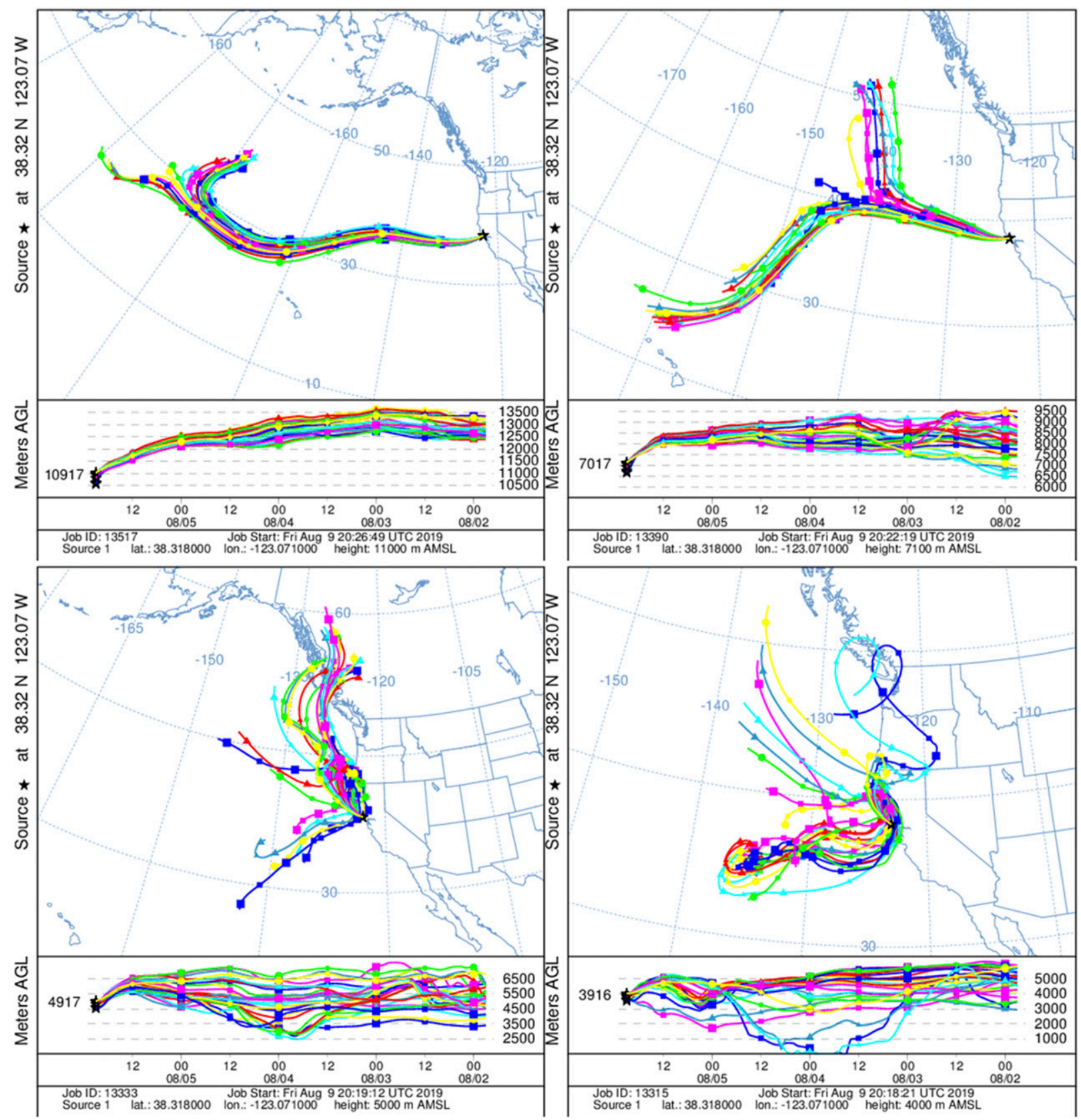

FIG. 7. NOAA HYSPLIT isentropic 96-h ensemble back trajectories for 2100 UTC 5 Aug 2016 at multiple elevations in the vertical column elevated above the BBY ozonesonde launch site.

6 August into $6 \mathrm{~km}$ as the embedded short-wave trough passed through the base of the trough of the enclosed upper-level low (Fig. 4). By 10 August 2016 the low-level tail of SI 3 influenced the region (Fig. 5) and low-level $\mathrm{O}_{3}$ increases were observed. By 11 August, the tail of SI 3 lifted and cut off from the upper SI 3 event and remains elevated above BBY. With the presence of higher pressure to the region, the high PV air mass began to descend toward the surface, reaching near $500 \mathrm{~m}$ the afternoon of 12 August and influencing the $\mathrm{sfcO}_{3}$ by 13 August (Fig. 9b). The arrival of the strong frontal passage allowed for the deep descent of stratospheric air into lowest levels of the vertical column elevated above BBY.

\section{c. $B B Y$ and $S A C$ maximum daily 8-h average $\mathrm{SfcO}_{3}$ analysis}

The $\mathrm{BBY} \mathrm{sfcO}_{3}$ monitoring data provided by BAAQMD reflects similar increases with time as those 

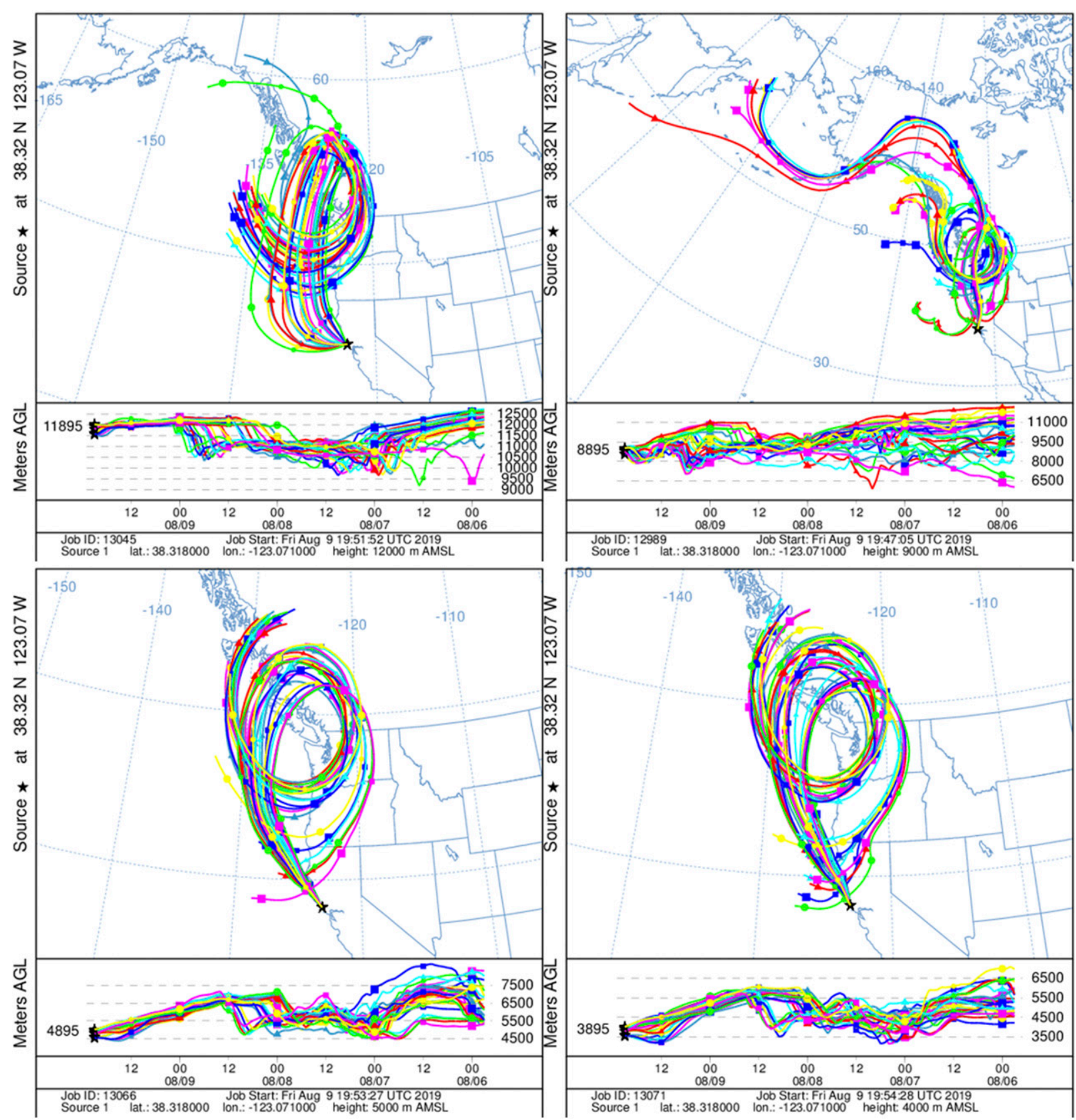

FIG. 8. NOAA HYSPLIT isentropic 96-h ensemble back trajectories for 2100 UTC 9 Aug 2016 at multiple elevations in the vertical column elevated above the BBY ozonesonde launch site.

inferred from the probable near-surface influence perceived in the SI 3 event at the end of the period (Fig. 9b). Also, while not fully discussed, a downward trend of increasing $\mathrm{O}_{3}$ can be inferred in the $\mathrm{BBY} \mathrm{sfcO}_{3}$ from the proposed lower-level stratospheric influence from upperlevel closed lows pointed out in Fig. 9a. Figure 10a shows the calculated BBY surface maximum daily 8-h average (MDA8) $\mathrm{O}_{3}$ values for 25 July-17 August 2016. Along with being a value of interest to the EPA, these averages are evaluated to reduce the effects of local pollution on the observed $\mathrm{sfCO}_{3}$ values (Parrish et al. 2010). The observed MDA8 $\mathrm{O}_{3}$ concentrations at BBY illustrate a small daily range of 2-10 ppb and the mean $\mathrm{MDA}_{8} \mathrm{O}_{3}$ value observed at BBY during the case study was near $20 \pm 5 \mathrm{ppb}$ (Fig. 10a).

The green boxes in Fig. 10a indicate dates that the strat $\mathrm{O}_{3}$ from 2 proposed SI events and the defined SI 3 event influenced the $\mathrm{sfcO}_{3}$ concentrations according to 

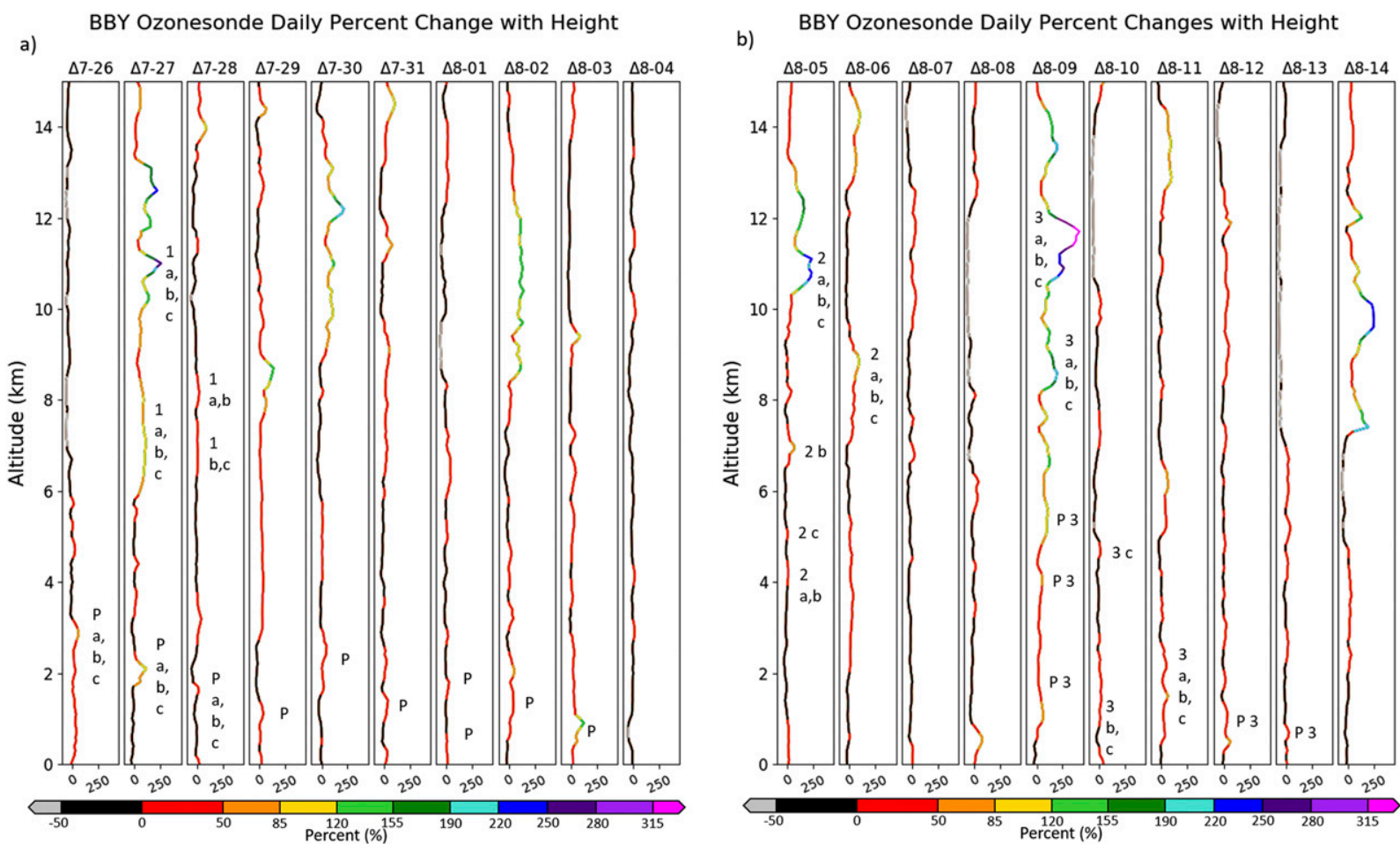

FIG. 9. (a) Calculated percent change in $\mathrm{O}_{3}$ from the BBY afternoon ozonesonde $100-\mathrm{m}$ average values from day to day, increases in $\mathrm{O}_{3}$ for SI 1 and plausible low-level intrusions $(\mathrm{P})$ are marked where $\mathrm{a}, \mathrm{b}$, and c specify which cross sections indicate high PV to the region, 26 Jul-4 Aug. (b) Calculated percent change in $\mathrm{O}_{3}$ from the BBY afternoon ozonesonde 100-m average values from day to day, increases in $\mathrm{O}_{3}$ for SI 2 and SI 3 with plausible low-level intrusion (P3) are marked where a, b, and c specify which cross sections indicate high PV to the region, 4-14 Aug.

the daily percent change in $\mathrm{O}_{3}$ analysis of BBY ozonesondes (Fig. 9). Figures $10 \mathrm{~b}$ and $10 \mathrm{c}$ show a 5-day period of minute-by-minute $\mathrm{sfCO}_{3}$ data collected on site. These images were created during the field study and included the time of the proposed influence of strat $\mathrm{O}_{3}$, also enclosed in green boxes. As the strat $\mathrm{O}_{3}$ from SI 3 reached the lowest $1 \mathrm{~km}$ (Figs. 9a,b), the onsite surface observations lack the presence of the typically expected overnight/early morning minimum $\mathrm{sfcO}_{3}$ observation. $\mathrm{StratO}_{3}$ from $\mathrm{SI} 3$ contributed to the 12 August late night and 13 August early morning $\mathrm{O}_{3}$ observations as a maximum in $\mathrm{SfCO}_{3}$ was reached for the 2-day period (Fig. 10c), with possible influence into the afternoon hours as ozonesonde data did indicate an increase in its lowest levels (Fig. 9b). $\mathrm{SfcO}_{3}$ influence from a proposed $\mathrm{SI}$ into the lower levels occurred early morning of 2 August from the initial influence of the upper-level closed low to the northwest (Fig. 10b). The final passing of the upper-level closed low to the northeast likely influenced $\mathrm{sfcO}_{3}$ concentrations on the night of 3 August, and the early morning of 4 August. Again, the time period exhibited little daily variation in the $\mathrm{sfCO}_{3}$ values (Fig. 10b).

Within SAC, the surface MDA8 $\mathrm{O}_{3}$ were calculated for 14 surface monitoring stations located across the southern Sacramento Valley and the local lower Sierra Nevada foothills. The monitoring sites were subcategorized into three groups based on elevation; high, middle, and low. These were defined by the elevation of the chosen sites accordingly: surface stations located (i) above $108 \mathrm{~m}$, (ii) between 108 and $47 \mathrm{~m}$, and (iii) below $47 \mathrm{~m}$. This conveniently groups the $\mathrm{sfcO}_{3}$ monitoring sites similarly by longitude. The high-elevation sites are located farthest east while the low-elevation sites are located farthest west (Fig. 1). Figure 10 shows the calculated MDA $8 \mathrm{O}_{3}$ values for each SAC surface monitoring site along with the BBY values for an easy comparison.

The mean MDA8 $\mathrm{O}_{3}$ observations were compared among all the surface monitoring sites. $\mathrm{O}_{3}$ observations at the inland SAC surface sites generally were greater than that observed at BBY and were representative of a larger daily range in MDA8 $\mathrm{O}_{3}$. In general, the mean MDA $8 \mathrm{O}_{3}$ concentrations were greatest at the highest elevation site and decrease with a corresponding decrease in height (Fig. 11). A mean MDA8 $\mathrm{O}_{3}$ of near 70 ppb was observed during the case study period at Grass Valley, typical of a site driven by local photochemical $\mathrm{O}_{3}$ production rather than long-range transport of $\mathrm{O}_{3}$. 

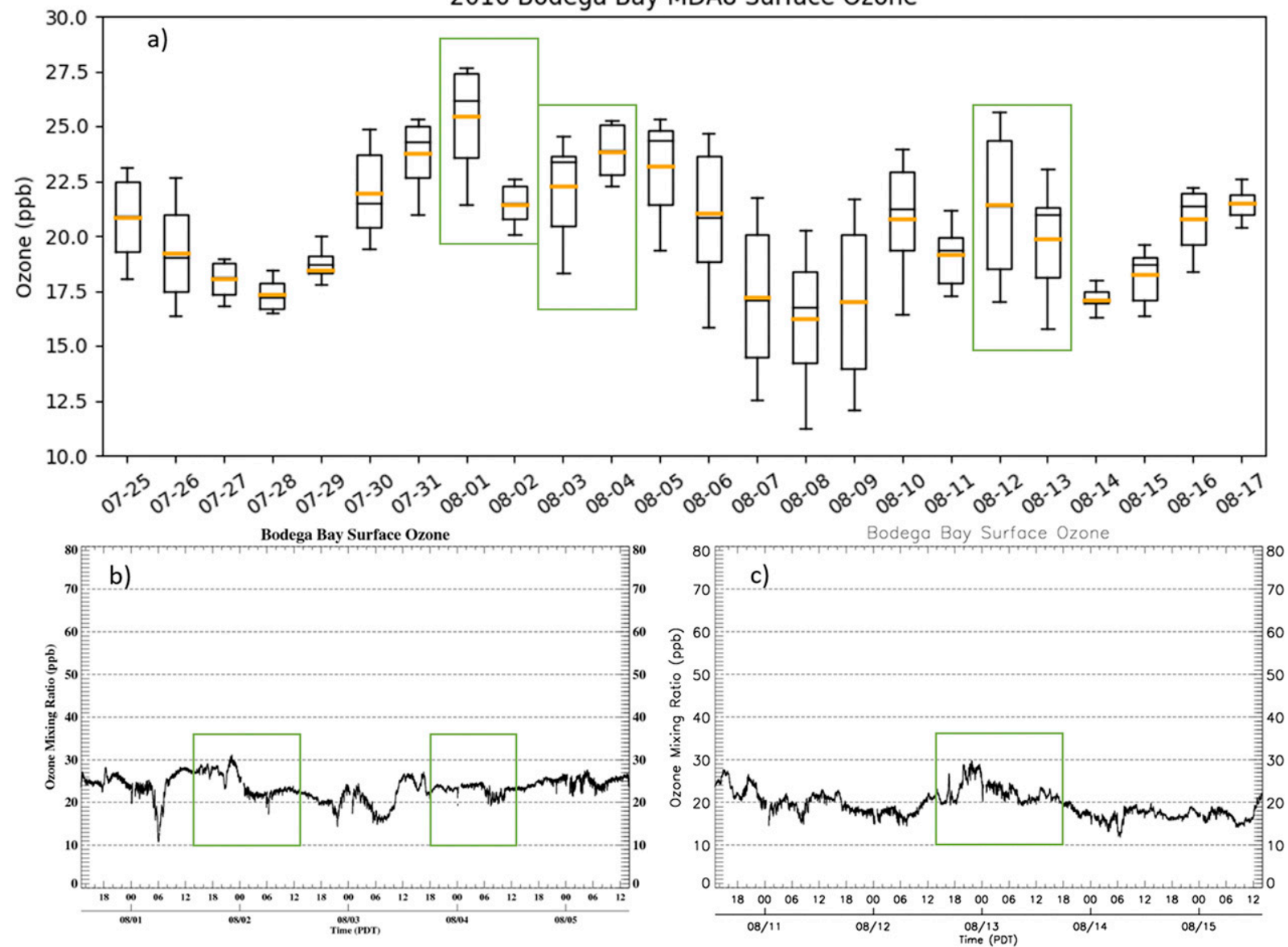

FIG. 10. (a) Classic boxplot for the calculated maximum daily 8-h average ozone at BBY for 25 Jul-17 Aug 2016, local hour 0 through 23 , orange bar = daily mean, black bar = daily median. (b) Onsite min-by-min $\mathrm{BBY}_{\mathrm{sfcO}}$ observations $30 \mathrm{Jul}-4 \mathrm{Aug}$. (c) Onsite min-by-min $\mathrm{BBY}$ sfcO ${ }_{3}$ observations $10-15$ Aug. Green boxes indicate dates and times that the $\operatorname{stratO}_{3}$ is suggested to have influenced the sfcO concentrations based on the ozonesonde analysis.

Similarly, mean $\mathrm{O}_{3}$ concentrations observed at the Colfax and Placerville sites were around 70 ppb (Fig. 11a). This observation alone creates a clear picture of the unhealthy surface air conditions and nonattainment of the region. The high-elevation monitoring sites observed mean MDA8 $\mathrm{O}_{3}$ values ranging between 50 and $80 \mathrm{ppb}$ for the study period (Fig. 11a). The mean $\mathrm{MDA} 8 \mathrm{O}_{3}$ observations at the mid- and low-elevation sites remained below the NAAQS. The midelevation monitoring sites observed concentrations for the period ranging from 30 to $60 \mathrm{ppb}$ and the low-elevation monitoring sites ranging from 20 to $50 \mathrm{ppb}$ (Figs. 11b,c). Dissimilar from the observations at $\mathrm{BBY}$, the mean MDA8 $\mathrm{O}_{3}$ values at the $\mathrm{SAC}$ surface sites were typically greater than or equal to the median (Fig. 11). The greatest exceptions occurred at the highelevation sites of Grass Valley and Placerville (Fig. 11a).

The daily range of MDA8 $\mathrm{O}_{3}$ observed among the SAC surface monitoring sites during the case study period were analyzed and compared with BBY data. All sites exhibit a much broader daily range of $\mathrm{O}_{3}$ concentration values than those observed at BBY. Even the smallest daily range observed at the rural Grass Valley site can easily double the typical daily range in MDA8 $\mathrm{O}_{3}$ found at BBY (Fig. 11a). This is expected as the much more rural BBY site is exposed to minimal urban emissions allowing for strat $\mathrm{O}_{3}$ to appear more prevalent at the surface.

An analysis of the lowest elevation surface monitoring site MDA8 $\mathrm{O}_{3}$ concentrations gives insight into the differences between coastal and inland sites of similar elevation and latitude. Elk Grove being the lowest elevation among all the sites at $7 \mathrm{~m}$ exhibits a substantially greater daily range of MDA8 $\mathrm{O}_{3}$ than that of BBY (Fig. 11c). This gives an indication of the impacts of high urban emissions at inland sites reacting with UV radiation in the formation and depletion of $\mathrm{O}_{3}$. The small 
(a)
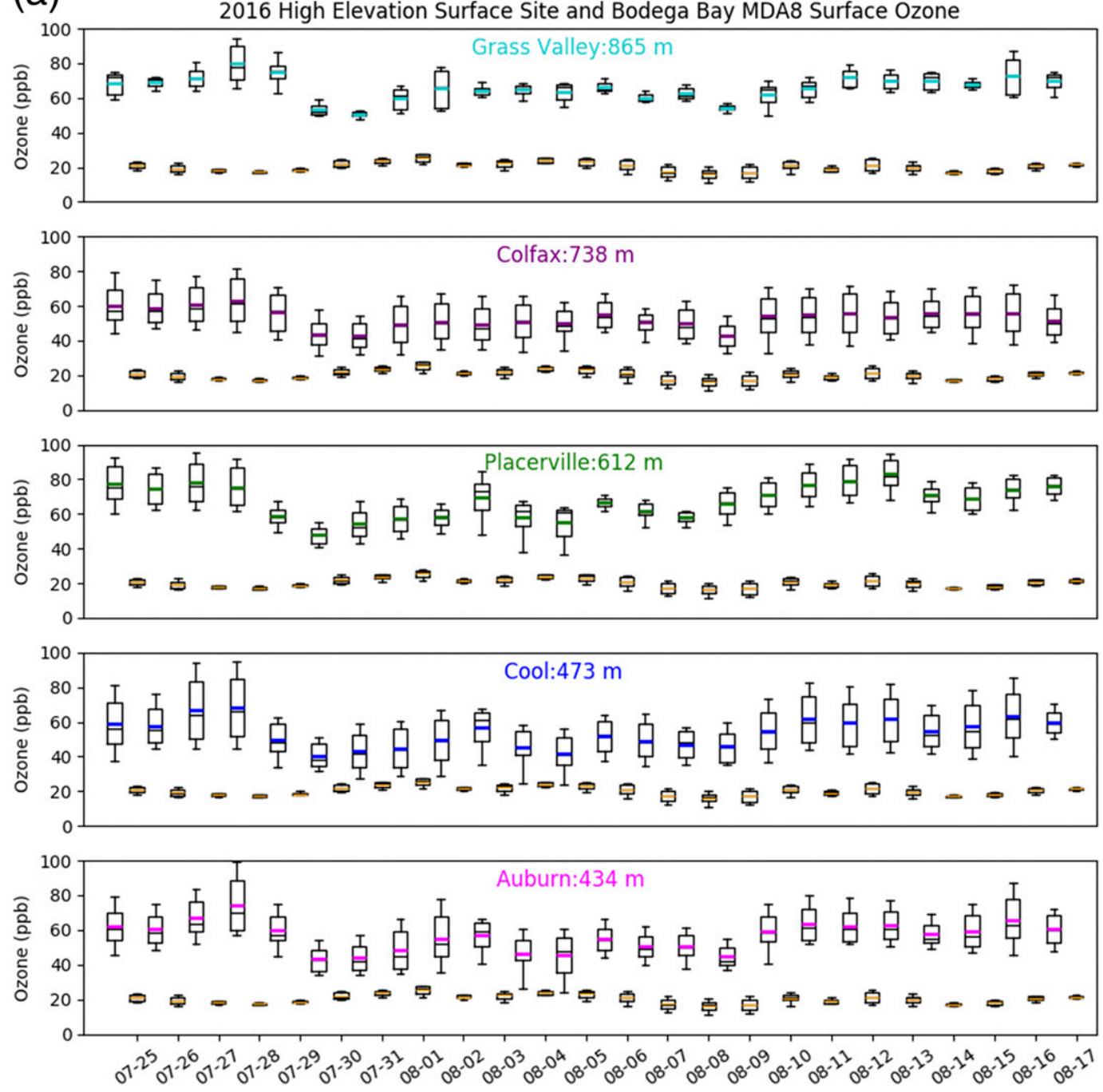

FIG. 11. Calculated surface MDA8 $\mathrm{O}_{3}$ concentration boxplots for 25 Jul-17 Aug 2016 for the SAC and BBY:

(a) high-, (b) mid-, (c) low-elevation surface sites; colored bar = daily mean, black bar = daily median.

daily range at $\mathrm{BBY}$ could indicate the importance of marine stratus clouds blocking the incoming solar radiation required for strong $\mathrm{O}_{3}$ formation and depletion.

\section{d. Correlations among sites}

A correlation analysis was performed utilizing the calculated surface MDA8 $\mathrm{O}_{3}$ values. The calculated correlation coefficients for the $15 \mathrm{sfcO}_{3}$ monitoring stations for 25 July through 17 August 2016 are recorded in Table 2. Correlations for the MDA8 $\mathrm{O}_{3}$ concentrations between two surface sites were calculated based on an exact date and hour comparison. The strongest correlations between individual surface monitoring stations MDA8 $\mathrm{O}_{3}$ concentrations were found to be within the subregion height category: low, middle, or high
(Table 2). It is important to note that while the correlations between the middle and low sites are all strong correlations, variations in correlation strength still occur. This shows the importance of latitude and longitude among the transport of urban emissions and other $\mathrm{O}_{3}$ precursors in the lower $110 \mathrm{~m}$ of the SAC air basin. The correlations among the high-elevation surface sites were weaker than those observed among the low and middle category sites.

Generally, as the distance between the two surface monitoring stations under comparison increases in the vertical and horizontal directions, the correlation becomes weaker. The Davis station located farthest west, the Elk Grove station located farthest south and lowest in elevation, and the Grass Valley station located 
(b)
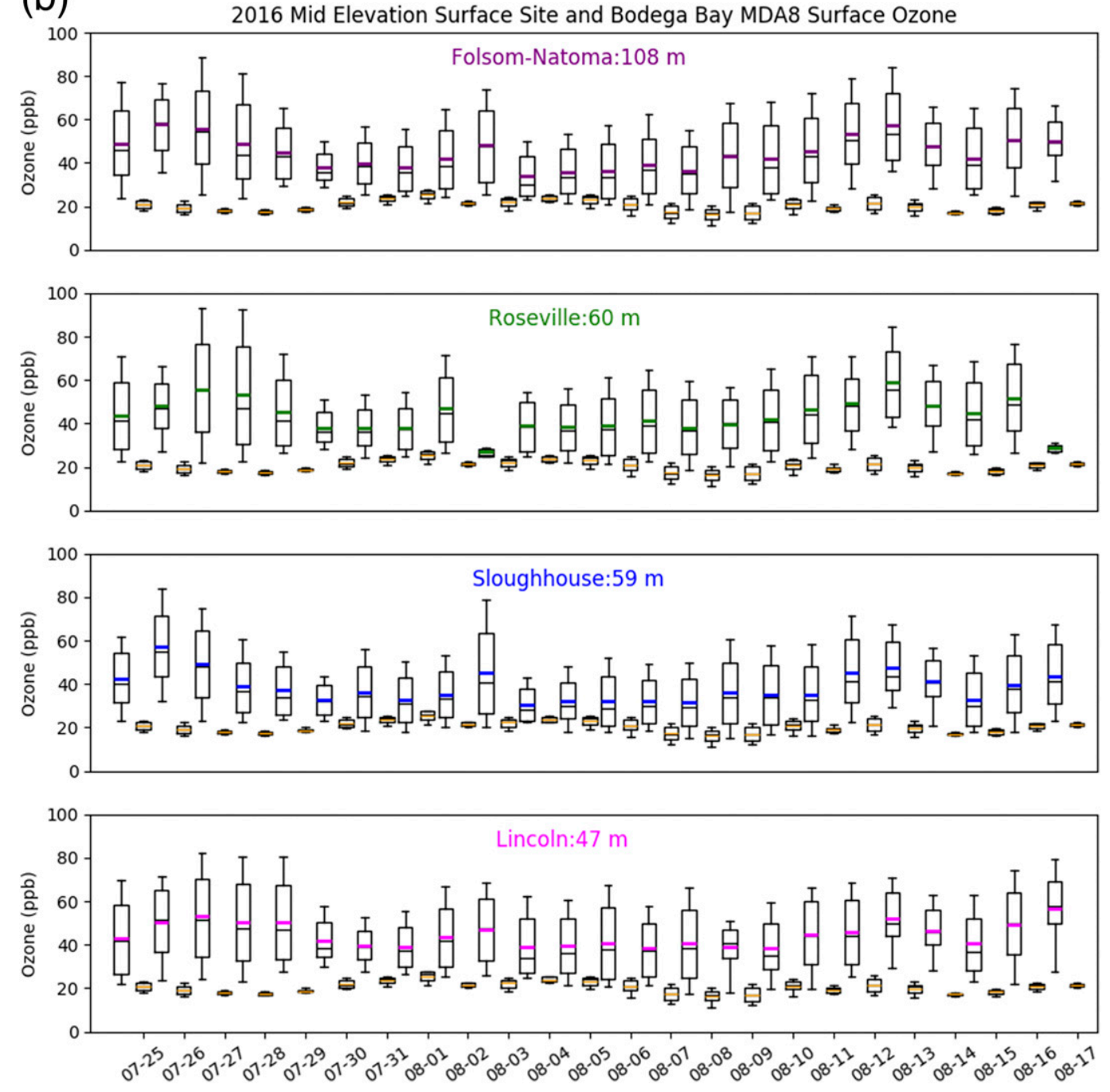

FIG. 11. (Continued)

farthest north and highest in elevation generally exhibited weaker correlations. Weak to little correlation was found between the calculated surface MDA $8 \mathrm{O}_{3}$ values for BBY and the SAC surface stations (Table 2).

The high-elevation surface sites display both positive and negative correlations with the BBY surface MDA8 $\mathrm{O}_{3}$ data (Table 2). The Colfax and the Cool sites exhibited very weak positive correlations with the BBY surface data, and stronger correlations with the SAC monitoring sites than did the other three high-elevation sites. The stronger correlations are likely due to the sites' near- $45^{\circ}$ bearing from the heart of Sacramento. Summertime thermally driven upslope flows are known to transport pollutants from Sacramento to the northeast Sierra Nevada foothills (Fast et al. 2012). Therefore, these sites would not be strong candidates to further understand strat $_{3}$ transport. Three sites, Auburn, Placerville, and Grass Valley, each displayed a very weak, negative correlation with BBY surface data, indicating a height dependency on the $\mathrm{O}_{3}$ correlation. For completion, a correlation analysis was performed between all five high-elevation sites and elevated BBY ozonesonde measurements of similar elevation.

The correlation analysis was performed as follows: between the afternoon BBY ozonesonde concentration between 400 and $1000 \mathrm{~m}$ at $100-\mathrm{m}$ increments and at $2000 \mathrm{~m}$, and the observed $2100 \mathrm{UTC}_{\mathrm{sfcO}}$ observation at the five high-elevation surface monitoring sites for the same date. This value represents the observation that is closest to the ozonesonde measurements obtained at 2100 UTC \pm 15 min to observe the well-known daily maximum $\mathrm{sfcO}_{3}$ concentration. The correlation 
(c)
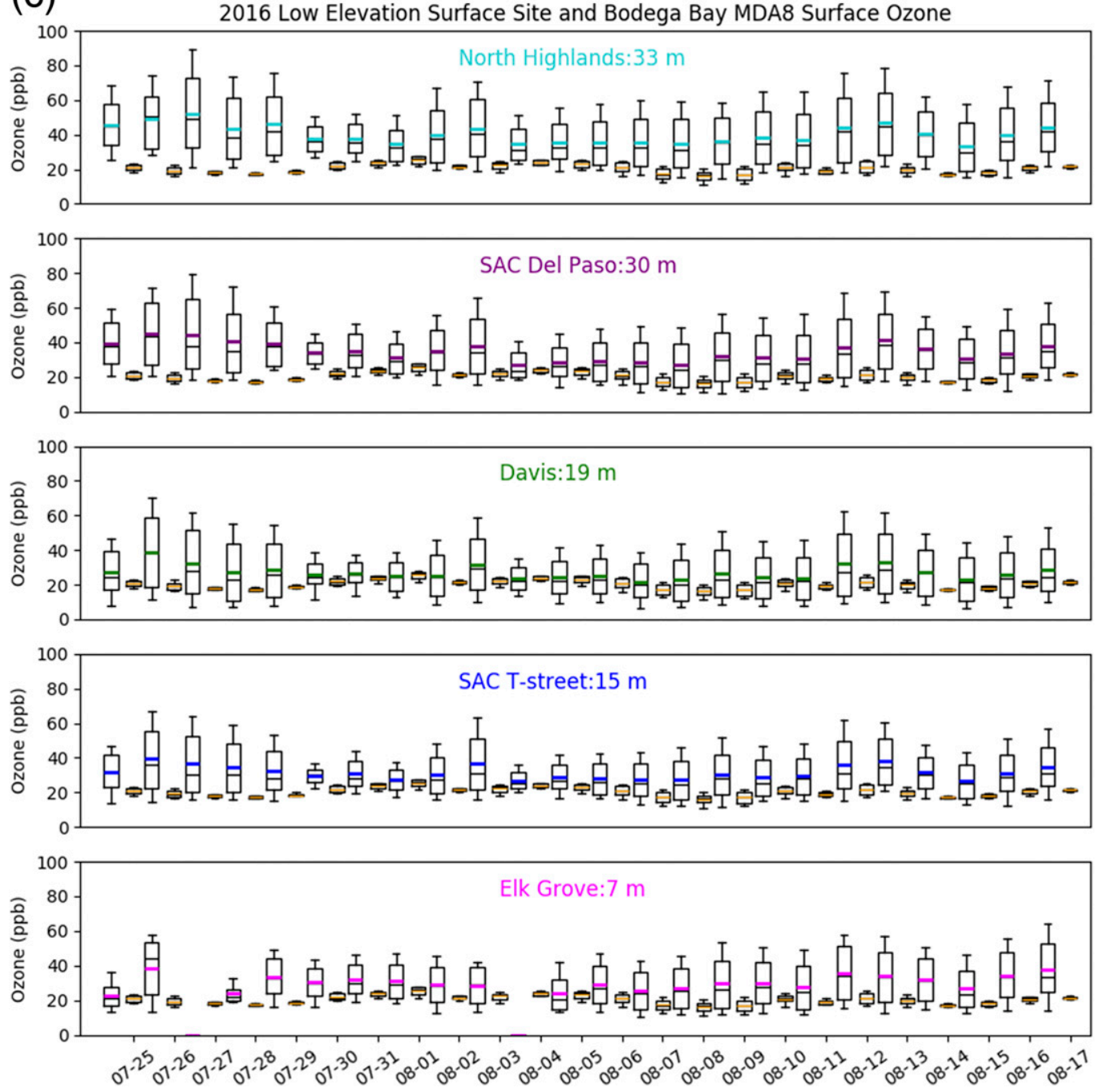

FIG. 11. (Continued)

coefficients are recorded in Table 3 . The $\mathrm{O}_{3}$ correlations became stronger, and sites that previously exhibited a negative correlation now display a positive correlation (Table 3). Of the five sites, the Placerville station, located roughly $200 \mathrm{~km}$ west from the BBY coast, exhibited the strongest correlations with the elevated BBY ozonesonde data. Therefore, the Placerville $\mathrm{O}_{3}$ observations were picked for further analysis.

An analysis of $\mathrm{sfcO}_{3}$ data at Placerville and elevated BBY ozonesonde data shows the similarities between the locations. A clear variance with height is noticeable in the correlation strength between the Placerville $\mathrm{sfcO}_{3}$ data and BBY ozonesonde measurements, especially at similar elevations (Table 3 ). Three elevations exhibited a moderately strong correlation of 0.61 and a dependent/independent factor of 0.37 for the case study period, a visual to these relationships are given with a linear regression plot (Fig. 12). Figure 13 shows the change in $\mathrm{O}_{3}$ concentration and percentage from one afternoon to the next at the three elevations of interest and at Placerville. It can be inferred that the $\mathrm{O}_{3}$ at either location are often influenced by the same source region, yet the strength of the impact varies and appears more influential at the North Bay area coastal site than the Sierra Nevada foothill surface site (Fig. 13). Of the observed daily $\mathrm{O}_{3}$ changes, on 10 dates the 4 locales $\mathrm{O}_{3}$ variance were either all positive or negative. Three groups of interesting data emerged from these daily $\mathrm{O}_{3}$ variations, and the dates listed in Table 4 are further discussed.

The first case emerged at the beginning of the period on 26 and 27 July. All sites exhibited an increase on 
TABLE 2. Correlation coefficients for the calculated MDA8 $\mathrm{O}_{3}$ comparison of exact time and hour observations for 25 Jul-17 Aug 2016 at two given stations. The SAC sites are listed in order of lowest elevation to highest elevation above sea level. The bold values highlight the strongest correlation for each surface monitoring station.

\begin{tabular}{|c|c|c|c|c|c|c|c|c|c|c|c|c|c|c|}
\hline & BBY & EG & $\mathrm{TSt}$ & Dvs & DP & $\mathrm{NH}$ & $\mathrm{Ln}$ & Sh & Rvle & $\mathrm{FN}$ & $\mathrm{Ab}$ & $\mathrm{Cl}$ & Pvle & Cfx \\
\hline EG & 0.385 & 1.000 & & & & & & & & & & & & \\
\hline TSt & 0.260 & 0.943 & 1.000 & & & & & & & & & & & \\
\hline Dvs & 0.247 & 0.941 & 0.967 & 1.000 & & & & & & & & & & \\
\hline DP & 0.241 & 0.948 & 0.980 & 0.954 & 1.000 & & & & & & & & & \\
\hline $\mathrm{NH}$ & 0.226 & 0.914 & 0.957 & 0.945 & 0.967 & 1.000 & & & & & & & & \\
\hline Ln & 0.200 & 0.907 & 0.916 & 0.885 & 0.924 & 0.921 & 1.000 & & & & & & & \\
\hline $\mathrm{Sh}$ & 0.222 & 0.916 & 0.957 & 0.915 & 0.959 & 0.940 & 0.902 & 1.000 & & & & & & \\
\hline Rvle & 0.138 & 0.890 & 0.920 & 0.877 & 0.933 & 0.926 & 0.935 & 0.905 & 1.000 & & & & & \\
\hline $\mathrm{FN}$ & 0.183 & 0.906 & 0.941 & 0.892 & 0.952 & 0.940 & 0.928 & 0.967 & 0.952 & 1.000 & & & & \\
\hline $\mathrm{Ab}$ & -0.017 & 0.688 & 0.710 & 0.663 & 0.742 & 0.751 & 0.795 & 0.749 & 0.822 & 0.816 & 1.000 & & & \\
\hline $\mathrm{Cl}$ & 0.040 & 0.783 & 0.792 & 0.752 & 0.815 & 0.821 & 0.842 & 0.823 & 0.886 & 0.890 & 0.943 & 1.000 & & \\
\hline Pvle & -0.062 & 0.478 & 0.584 & 0.490 & 0.593 & 0.569 & 0.618 & 0.675 & 0.673 & 0.736 & 0.811 & 0.836 & 1.000 & \\
\hline $\mathrm{Cfx}$ & 0.095 & 0.792 & 0.809 & 0.805 & 0.831 & 0.843 & 0.836 & 0.810 & 0.854 & 0.839 & 0.888 & 0.895 & 0.674 & 1.000 \\
\hline $\mathrm{GV}$ & -0.157 & 0.066 & 0.122 & 0.020 & 0.160 & 0.155 & 0.257 & 0.224 & 0.228 & 0.279 & 0.575 & 0.436 & 0.434 & 0.434 \\
\hline
\end{tabular}

26 July, followed by a decrease on 27 July (Fig. 13). The daily afternoon $\mathrm{O}_{3}$ changes were similar in value, if not matching (Table 4). It can be inferred from Fig. 2a that the tropopause was low in the days prior. This likely resulted in stratO $\mathrm{O}_{3}$ transport into the lower troposphere due to a rapid change in tropopause height (Hocking et al. 2007). Contributing to the case of stratospheric influence was high PV in the $0.5-1.0 \mathrm{~km}$ (Fig. 3). On 27 July, the observed BBY ozonesonde values approached $120 \mathrm{ppb}$ at $2 \mathrm{~km}$ (Fig. $2 \mathrm{~b}$ ), as the Soberanes fire in Monterey County had another outbreak (Center for Atmospheric Research and Education 2016).

The second case of interest occurred from 3 to 4 August. The daily changes in $\mathrm{O}_{3}$ are the greatest of the period (Fig. 13). The observations on 2 August show an increase throughout most of the $1-5 \mathrm{~km}$ column, with a downward trend on 3 August and a large spike at $1 \mathrm{~km}$, corresponding with the downward progression of a proposed low-level intrusion (Fig. 9a). During the launch on 3 August, the observed concentrations at $1 \mathrm{~km}$ reached $100 \mathrm{ppb}$ (Fig. 2b). Though there are signs of stratospheric influence, these data were also subject to fire influences. The Cold Fire in Yolo County was active and located between Placerville and the BBY coast (Center for Atmospheric Research and Education 2016).

The strongest case for quantifying strat $\mathrm{O}_{3}$ transport into the lower $1 \mathrm{~km}$ was the final case, 11 August through 14 August, and corresponds with SI 3. There were no fire outbreaks or growth and the Cold Fire had been extinguished. The $\mathrm{O}_{3}$ variances at Placerville were very similar to that observed in the elevated BBY ozonesonde data. Figure 12 shows an observed increase in $\mathrm{O}_{3}$ at BBY 0.6-1.0 km and Placerville on 11 and 12 August, followed by a decrease in $\mathrm{O}_{3}$ at $1.0 \mathrm{~km}$ and Placerville on 13 August, and then a decrease in $\mathrm{O}_{3}$ at all levels on 14 August. Observations on 10 August show an increase in $\mathrm{O}_{3}$ at $1 \mathrm{~km}$ and Placerville, no change to $800-\mathrm{m} \mathrm{O}_{3}$, and a decrease in $600-\mathrm{m} \mathrm{O}_{3}$. Daily $\mathrm{O}_{3}$ variations at Placerville appear to follow more closely with the time fluctuations at $1 \mathrm{~km}$; the daily $\mathrm{O}_{3}$ concentration changes were most like those observed at BBY $600 \mathrm{~m}$. This analysis shows that the $0.6-1.0 \mathrm{~km}$ elevated region was influenced by $10-20 \mathrm{ppb}$ of $\mathrm{stratO}_{3}$ per day as it progressed downward on 11-14 August 2016 above Northern California, at least during the afternoon peak $\mathrm{O}_{3}$ h (Table 4).

TABLE 3. Correlation coefficients for high-elevation $\mathrm{sfcO}_{3}$ values observed for the 2100 UTC hour with elevated Bodega Bay 2100 UTC ozonesonde measurements. The italicized values denote the three strongest correlations observed, the bold highlight the strongest correlation for each surface monitoring station.

\begin{tabular}{|c|c|c|c|c|c|c|c|c|}
\hline Correlation coefficient & BBY: $400 \mathrm{~m}$ & BBY: $500 \mathrm{~m}$ & BBY: $600 \mathrm{~m}$ & BBY: $700 \mathrm{~m}$ & BBY: $800 \mathrm{~m}$ & BBY: $900 \mathrm{~m}$ & BBY: $1 \mathrm{~km}$ & $\mathrm{BBY}: 2 \mathrm{~km}$ \\
\hline Auburn 2100 UTC & 0.129 & 0.171 & 0.313 & 0.317 & 0.304 & 0.207 & 0.193 & 0.561 \\
\hline Cool 2100 UTC & 0.277 & 0.346 & 0.434 & 0.421 & 0.408 & 0.307 & 0.299 & 0.506 \\
\hline Placerville 2100 UTC & 0.497 & 0.578 & 0.608 & 0.573 & 0.613 & 0.577 & 0.609 & 0.496 \\
\hline Colfax 2100 UTC & 0.294 & 0.245 & 0.285 & 0.285 & 0.287 & 0.221 & 0.294 & 0.429 \\
\hline Grass Valley 2100 UTC & 0.220 & 0.291 & 0.327 & 0.364 & 0.379 & 0.292 & 0.322 & 0.378 \\
\hline
\end{tabular}




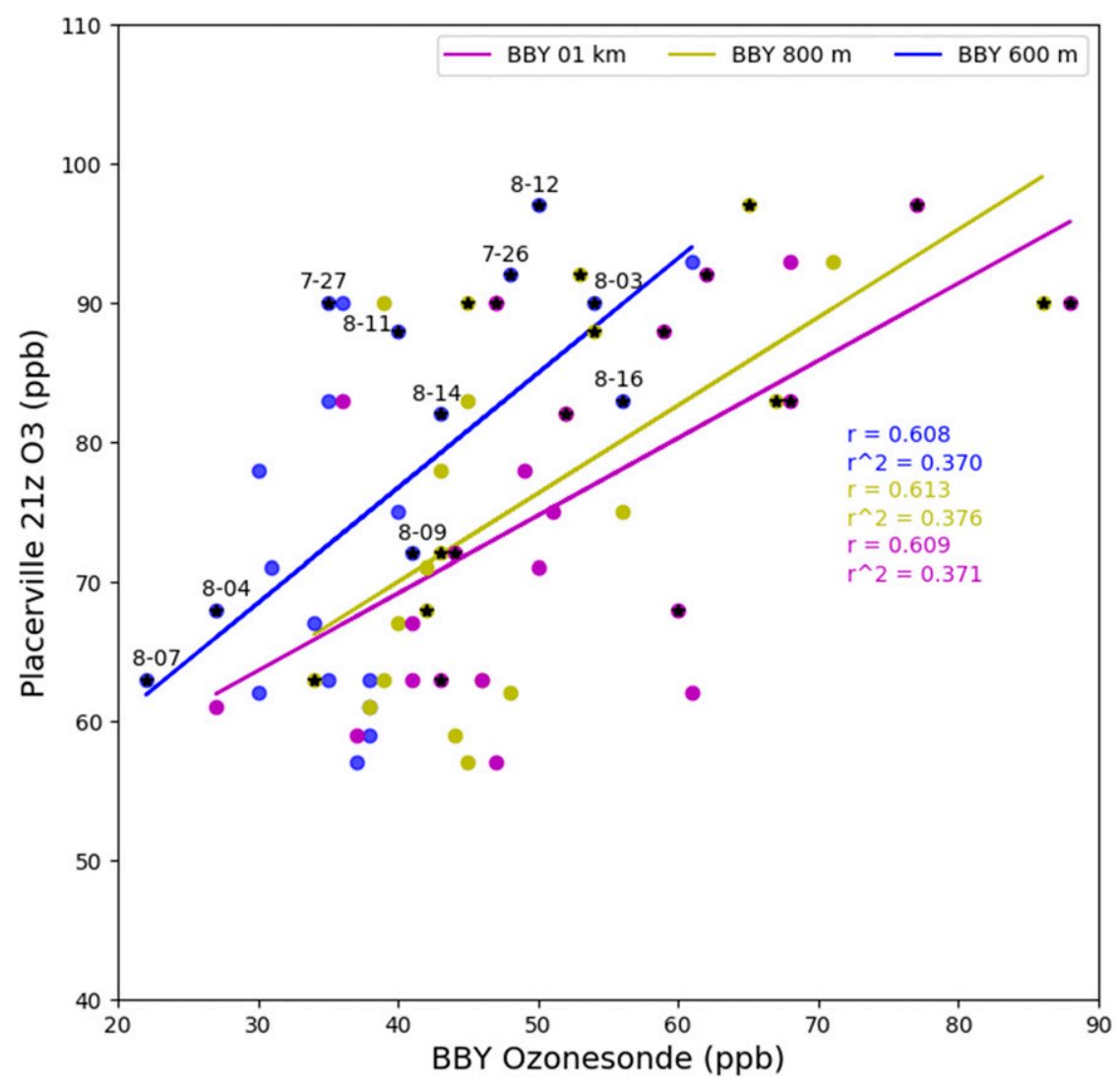

FIG. 12. Linear regression plot for elevated BBY observed $\mathrm{O}_{3}$ and Placerville 2100 UTC observed surface station $\mathrm{O}_{3}$ for the case study period $25 \mathrm{Jul}-16$ Aug 2016; dots are observations.

\section{Conclusions}

Stratospheric intrusions are known to be plentiful above the California region, especially along the North Pacific storm tracks. It is widely accepted that the observed values of $\mathrm{O}_{3}$ measured at western coastal sites are a good indication of $\mathrm{bgO}_{3}$ values due to the prevailing onshore flow. Therefore, the $\mathrm{O}_{3}$ concentrations measured at BBY show the temporal variability of $\mathrm{bgO}_{3}$ due to SI without strong anthropogenic influences. This study highlights that using 1.0 PVU is adequate to observe the deep penetration of stratospheric air masses into the lower troposphere above Northern California. The results show that high $\mathrm{O}_{3}$ incidences due to plausible deep SI effect coastal $\mathrm{sfcO}_{3}$ levels during the 2016 $\mathrm{NH}$ summer (e.g., from late July to early August) and likely influence $\mathrm{sfcO}_{3}$ levels in the SAC, and describes a likely synoptic setup that potentially brings stratospheric ozone influence to the lower troposphere in the California region of interest, likely influencing surface ozone concentrations directly.

This study identifies the downward vertical transport of $\mathrm{O}_{3}$ from the point of stratospheric injection to the surface at BBY. Other studies have similarly recognized transport of strat $\mathrm{O}_{3}$ to within the BL (e.g., Hocking et al. 2007; Tarasick et al. 2019). For this study, in regions of the strat $\mathrm{O}_{3}$ intrusion events, a downward progression of increasing $\mathrm{O}_{3}$ with time is distinct within the BBY ozonesonde daily percent change data. The positive increase in $\mathrm{O}_{3}$ was tracked downward, reaching the lowest $1 \mathrm{~km}$ of the ozonesonde profile and the surface. These $\mathrm{O}_{3}$ increases were noticeable in the overnight surface monitoring data from on site. This study also recognizes the similarities detected within the MERRA-2 values of PV for the vertical cross section including BBY and the SAC. It appears that the $\mathrm{O}_{3}$ measurements captured by the $\mathrm{BBY}$ ozonesonde give a good indication of $\mathrm{O}_{3}$ concentrations elevated high above the SAC. The greatest impacts of baseline $\mathrm{O}_{3}$ entering California above $2 \mathrm{~km}$ is within the elevated terrain of eastern California (Cooper et al. 2011). For this case the strongest spatial similarities exhibited were above $2 \mathrm{~km}$ mean sea level.

During this selected time frame, the SAC air quality proved to be moderate to harmful. However, the 


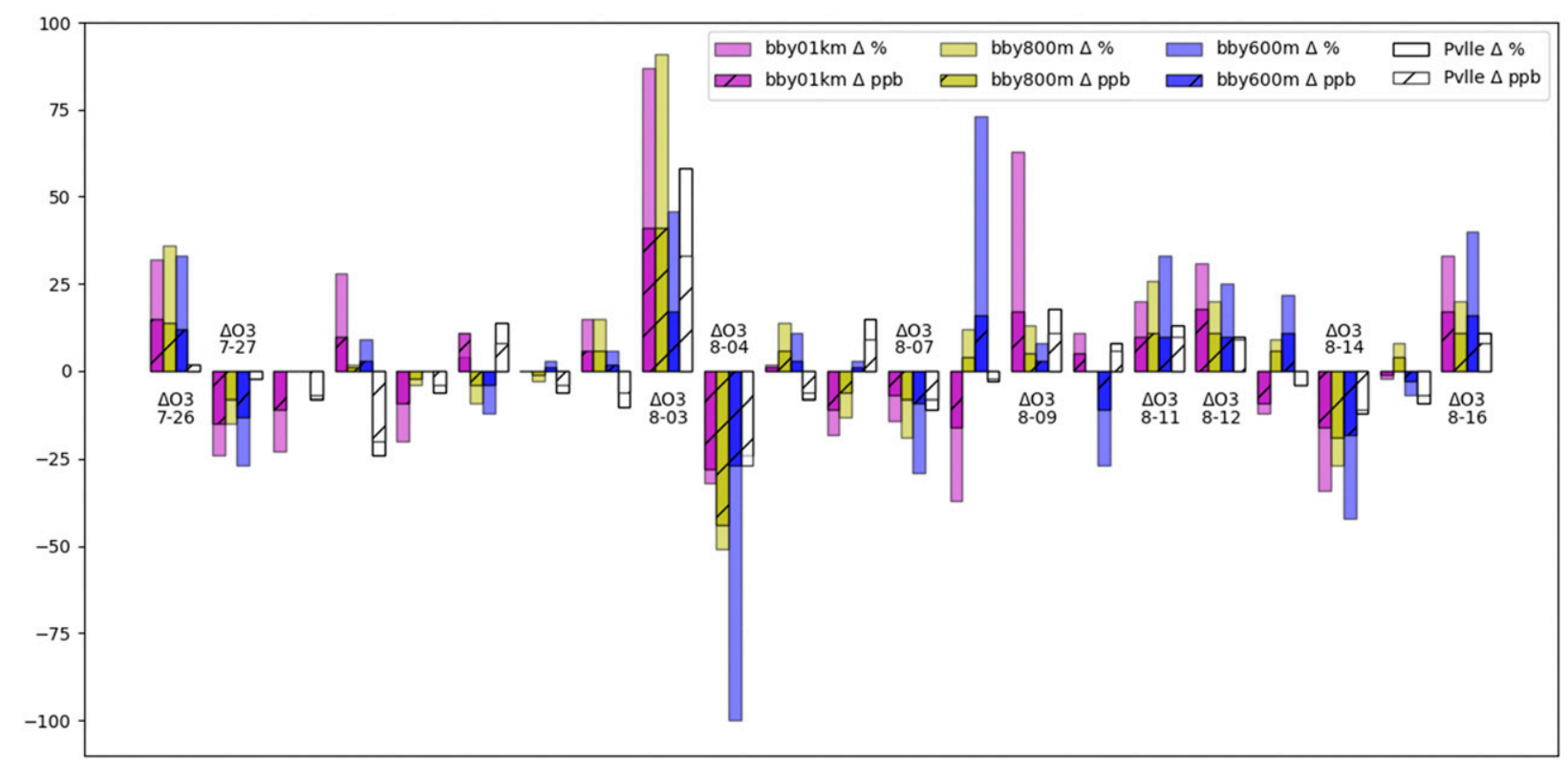

FIG. 13. Daily observed ozone variations, in both changes in percentage (solid bar) and in concentration (hatched bar), for three elevated BBY locations ozonesonde observations (colors) and 2100 UTC Placerville $\mathrm{sfcO}_{3}$ observations (white); case study period 25 Jul-16 Aug.

high-elevation surface sites often contributed to this nonattainment. Also, the reduced daily range of $\mathrm{MDA} 8 \mathrm{O}_{3}$ at the high-elevation sites indicates a greater influence of $\mathrm{bgO}_{3}$ than local $\mathrm{O}_{3}$ pollution in comparison to the lowerelevation sites. Although observed $\mathrm{O}_{3}$ concentrations were very similar when sites are in close proximity, the small difference shows that $\mathrm{O}_{3}$ is highly variable. This implies that correlations between observations of $\mathrm{O}_{3}$ concentrations at similar altitude over a greater distance would not be expected to be strong. A moderate correlation would indicate that air masses observed at two sites become regionally similar during events that cover a greater region simultaneously, such as during SI.

Elevated surface monitoring sites in the lower foothills of SAC can be separated into two categories. The first category includes sites where $\mathrm{O}_{3}$ observations are influenced by lower-elevation surface pollution.
The Colfax monitoring site has a strong correlation with most of the SAC surface monitoring sites. The correlation found between the Colfax $\mathrm{scO}_{3}$ and the elevated BBY ozonesonde data remained weaker than that observed with the lower-elevation SAC site (Table 3). This further contributes to knowledge of surface pollution from the heart of Sacramento being transported northeasterly upslope to the Sierra Nevada foothills. The second category includes sites that are influenced by the $\mathrm{O}_{3}$ in an upper-level air mass. A height dependency correlation between BBY and high-surface-elevation sites in SAC shows a change from a weak negative correlation to a moderate positive correlation for three $\mathrm{O}_{3}$ monitoring sites; Grass Valley, Placerville, and Auburn. This shows that $\mathrm{O}_{3}$ concentrations observed at these surface sites were more closely related to mixing from the air above than below.

TABLE 4. $\mathrm{O}_{3}$ observations and daily changes $(\Delta)$ in $\mathrm{O}_{3}$ concentration and percent from the date prior observed at the three elevated BBY points of interest and at the Placerville surface monitoring station during the dates of interest.

\begin{tabular}{|c|c|c|c|c|c|c|c|c|c|c|c|c|}
\hline \multirow[b]{2}{*}{ Date } & \multicolumn{3}{|c|}{ BBY: $1 \mathrm{~km}$} & \multicolumn{3}{|c|}{ BBY: $800 \mathrm{~m}$} & \multicolumn{3}{|c|}{ BBY: $600 \mathrm{~m}$} & \multicolumn{3}{|c|}{ Placerville: $612 \mathrm{~m}$} \\
\hline & $\mathrm{ppb}$ & $\Delta \mathrm{ppb}$ & $\Delta \mathrm{O}_{3} \%$ & $\mathrm{ppb}$ & $\Delta \mathrm{ppb}$ & $\Delta \mathrm{O}_{3} \%$ & $\overline{\mathrm{ppb}}$ & $\Delta \mathrm{ppb}$ & $\Delta \mathrm{O}_{3} \%$ & $\overline{\mathrm{ppb}}$ & $\Delta \mathrm{ppb}$ & $\Delta \mathrm{O}_{3} \%$ \\
\hline $26 \mathrm{Jul}$ & 62 & 15 & 32 & 53 & 14 & 36 & 48 & 12 & 33 & 92 & 2 & 2 \\
\hline $27 \mathrm{Jul}$ & 47 & -15 & -24 & 45 & -8 & -15 & 35 & -13 & -27 & 90 & -2 & -2 \\
\hline 3 Aug & 88 & 41 & 87 & 86 & 41 & 91 & 54 & 17 & 46 & 90 & 33 & 58 \\
\hline 4 Aug & 60 & -28 & -32 & 42 & -44 & -51 & 27 & -27 & -100 & 68 & -22 & -24 \\
\hline 11 Aug & 59 & 10 & 20 & 54 & 11 & 26 & 40 & 10 & 33 & 88 & 10 & 13 \\
\hline 12 Aug & 77 & 18 & 31 & 65 & 11 & 20 & 50 & 10 & 25 & 97 & 9 & 10 \\
\hline 13 Aug & 68 & -9 & -12 & 71 & 6 & 9 & 61 & 11 & 22 & 93 & -4 & -4 \\
\hline 14 Aug & 52 & -16 & -34 & 52 & -19 & -27 & 43 & -18 & -42 & 82 & -11 & -12 \\
\hline
\end{tabular}


This study demonstrates that $\mathrm{sfcO}_{3}$ in Placerville and the air mass elevated above BBY were influenced similarly by strat $\mathrm{O}_{3}$ during a SI to the region of Northern California. A moderately strong correlation was found between the observed afternoon Placerville $\mathrm{sfcO}_{3}$ concentrations and the elevated BBY ozonesonde data at similar elevations. Observations between the three strongest correlated $\mathrm{BBY}$ elevated $\mathrm{O}_{3}$ and Placerville show that daily changes in $\mathrm{O}_{3}$ at all locations exhibited days where the $\mathrm{O}_{3}$ substantially increased, and a decrease the following day. The case of 11 August, the concentration changes under observation were near identical. The occurrence of this is suggestive of both locations simultaneously being influenced highly by $\mathrm{bgO}_{3}$ that is stratospheric in nature and can be considered a regional influence. Therefore, a closer study of the vertical column of $\mathrm{O}_{3}$ above both the BBY and SAC regions, during forecasted SIs in spring when events are most prevalent, via simultaneous ozonesonde launches would be beneficial.

While this study has merit in defining two locations that, if studied further, would lead to better estimations of strat $\mathrm{O}_{3}$ surface influence in Northern California and introduces a useful set of $\mathrm{O}_{3}$ data for future atmospheric and air quality modeling studies, it has limitations. The ozonesonde dataset was a contribution to the larger CABOTS 2016 air quality campaign. The NASA flights and NOAA ground-based lidar measurements took focus to the south in the San Joaquin Valley, and the deployment time of these platforms did not line up consistently with the time frame of this study. A similar campaign design with focus in SAC could lead to quantifying the direct influence of strat $\mathrm{O}_{3}$ contributing to the total $\mathrm{sfcO}_{3}$ pollution in the nonattainment zone.

Questions emerge about the linkage between high PV descending to the lower stratosphere and the timing of the wildfire influence on the region. While this study uses 3 different vertical cross sections for the analysis of the arrival of high PV into BBY, the picture is not complete. There were multiple probable lower-level strat $\mathrm{O}_{3}$ intrusions that occurred in correspondence with the upper-level enclosed lows that crossed through British Columbia and the Pacific Northwest prior to the period, and between SI 1 and SI 2. Further study into the exact location and timing of the wildfires could link dry stratospheric air, rich in $\mathrm{O}_{3}$, with the strength of a firestorm. Previous studies do suggest that fires are affected by SIs (Charney et al. 2003; Zimet et al. 2007; Langford et al. 2015). Future work will perform a trajectory analysis for the dates of interest, leading to answers of how often the air entering these locations crosses the same path, taking on influences of similar air masses.

Acknowledgments. We acknowledge the suppliers of datasets utilized in this research. We wish to express our appreciation to Drs. Jin Xue and Andy Langford for the suggestions for the development of this research. Proofreading by Dr. Ju-mee Ryoo was much appreciated. Comments and suggestions from three anonymous reviewers were highly appreciated. This research was supported by the NASA MUREP Grant NNX15AQ02A and the California Air Resources Board Contract 15RD007. The research is based on the thesis research of the first author and repeated in this paper with permission.

\section{REFERENCES}

Bourqui, M. S., and P.-Y. Trépanier, 2010: Descent of deep stratospheric intrusions during the ION August 2006 campaign. J. Geophys. Res., 115, D18301, https://doi.org/ 10.1029/2009JD013183.

Center for Atmospheric Research and Education, 2016: Bodega Bay Launch Blog. San Jose State University, accessed 16 September 2018, sites.google.com/a/sjsu.edu/cabots-sjsu/ daily-blog.

Charney, J. J., X. Bian, B. E. Potter, and W. E. Heilman, 2003: The role of a stratospheric intrusion in the evolution of the Double Trouble State Park Wildfire. Fifth Symp. on Fire and Forest Meteorology, Orlando, FL, Amer. Meteor. Soc., P5.3, https:// ams.confex.com/ams/pdfpapers/65830.pdf.

Clark, J., 2018: Stratospheric intrusions over Northern California during CABOTS: A study of ozone transport and the influence on surface ozone pollution in the Sacramento Valley. M.S. thesis, Dept. of Meteorology and Climate Science, San Jose University, 4932, 80 pp., https://doi.org/10.31979/etd.9xwh-897f.

Cooper, O. R., and Coauthors, 2001: Trace gas signatures of the airstreams within the North Atlantic cyclones: Case studies from the NARE'97 aircraft intensive. J. Geophys. Res., 106, 5437-5456, https://doi.org/10.1029/2000JD900574.

_ , and Coauthors, 2011: Measurement of western U.S. baseline ozone from the surface to the tropopause and assessment of downwind impact regions. J. Geophys. Res., 116, D00V03, https://doi.org/10.1029/2011JD016095.

Cox, B. D., M. Bithell, and L. J. Gray, 1997: Modelling of stratospheric intrusions within a mid-latitude synoptic-scale disturbance. Quart. J. Roy. Meteor. Soc., 123, 1377-1403, https:// doi.org/10.1002/qj.49712354112.

Danielsen, E. F., R. S. Hipskind, S. E. Gaines, G. W. Sachse, G. L. Gregory, and G. G. Hill, 1987: Three-dimensional analysis of potential vorticity associated with tropopause folds and observed variations in ozone and carbon monoxide. J. Geophys. Res., 92, 2103-2111, https://doi.org/10.1029/ JD092iD02p02103.

Ding, A., and T. Wang, 2006: Influence of stratosphere-totroposphere exchange in the seasonal cycle of surface ozone at Mount Wiliguan in western China. Geophys. Res. Lett., 33, L03803, https://doi.org/10.1029/2005GL024760.

Fast, J. D., and Coauthors, 2012: Transport and mixing patterns over Central California during the carbonaceous aerosol and radiative effects study (CARES). Atmos. Chem. Phys., 12, 1759-1783, https://doi.org/10.5194/acp-12-1759-2012.

Hocking, W. K., T. Carey-Smith, D. Tarasick, S. Argall, K. Strong, Y. Rochon, I. Zawadzki, and P. Taylor, 2007: Detection of stratospheric ozone intrusions by windprofiler radars. Nature, 450, 281-284, https://doi.org/10.1038/nature06312. 
Hoskins, B. J., M. E. McIntyre, and A. W. Robertson, 1985: On the use and significance of isentropic potential vorticity maps. Quart. J. Roy. Meteor. Soc., 111, 877-946, https://doi.org/ 10.1002/qj.49711147002.

Hsu, J., and M. J. Prather, 2009: Stratospheric variability and tropospheric ozone. J. Geophys. Res., 114, D06102, https:// doi.org/10.1029/2008JD010942.

Knowland, K.E., Ott, L.E., Duncan, B.N., Wargan, K., 2017: Stratospheric intrusion-influenced ozone air quality exceedances investigated in the NASA MERRA-2 reanalysis. Geophys. Res. Lett., 44, $10691-10701$, https://doi.org/ 10.1002/2017GL074532.

Langford, A. O., K. C. Aikin, C. S. Eubank, and E. J. Williams, 2009: Stratospheric contribution to high surface ozone in Colorado during springtime. Geophys. Res. Lett., 36, L12801, https://doi.org/10.1029/2009GL038367.

_ R. B. Pierce, and P. J. Schultz, 2015: Stratospheric intrusions, the Santa Ana winds, and wildland fires in Southern California. Geophys. Res. Lett., 42, 6091-6097, https://doi.org/10.1002/ 2015 GL064964.

Lefohn, A. S., H. Wernli, D. Shadwick, S. J. Oltmans, and M. Shapiro, 2012: Quantifying the importance of stratospheric- tropospheric transport on surface ozone concentrations at high- and low-elevation monitoring sites in the United States. Atmos. Environ., 62, 646-656, https://doi.org/10.1016/ j.atmosenv.2012.09.004.

Lin, M., and Coauthors, 2012: Springtime high surface ozone events over the western United States: Quantifying the role of stratospheric intrusions. J. Geophys. Res., 117, D00V22, https://doi.org/10.1029/2012JD018151.

- A. M. Fiore, L. W. Horowitz, A. O. Langford, S. J. Oltmans, D. Tarasick, and H. E. Rieder, 2015: Climate variability modulates western US ozone air quality in spring via deep stratospheric intrusions. Nat. Commun., 6, 7105, https:// doi.org/10.1038/ncomms8105.

Liu, G., D. W. Tarasick, V. E. Fioletov, C. E. Sioris, and Y. J. Rochon, 2009: Ozone correlation lengths and measurement uncertainties from analysis of historical ozonesonde data in North America and Europe. J. Geophys. Res., 114, D04112, https://doi.org/10.1029/2008JD010576.

Oltmans, S. J., and Coauthors, 1996: Summer and spring ozone profiles over the North Atlantic from ozonesonde measurements. J. Geophys. Res., 101, 29179-29200, https://doi.org/ 10.1029/96JD01713.

—, A. S. Lefohn, J. M. Harris, and D. S. Shadwick, 2008: Background ozone levels of air entering the west coast of the US and assessment of longer-term changes. Atmos. Environ., 42, 6020-6038, https://doi.org/10.1016/j.atmosenv.2008.03.034

Parrish, D. D., K. C. Aikin, S. J. Oltmans, B. J. Johnson, M. Ives, and C. Sweeny, 2010: Impact of transported background ozone inflow on summertime air quality in a California ozone exceedance area. Atmos. Chem. Phys., 10, 10 093-10 109, https:// doi.org/10.5194/acp-10-10093-2010.

Roelofs, G. J., and Coauthors, 2003: Intercomparison of tropospheric ozone models: Ozone transport in a complex tropopause folding event. J. Geophys. Res., 108, 8529, https://doi.org/10.1029/2003JD003462.

Ryoo, J.-M., D. W. Waugh, and A. Gettelman, 2008: Variability of subtropical upper tropospheric humidity. Atmos. Chem. Phys., 8, 2643-2655, https://doi.org/10.5194/acp-8-2643-2008.

M. S. Johnson, E. L. Yates, L. T. Iraci, R. B. Pierce, T. Tanaka, and W. Gore, 2017: Investigating sources of ozone over California using AJAX airborne measurements and models: Assessing the contribution from long-range transport. Atmos. Environ., 155, 53-67, https://doi.org/10.1016/ j.atmosenv.2017.02.008.

Škerlak, B., M. Sprenger, and H. Wernli, 2014: A global climatology of stratosphere-troposphere exchange using the ERAInterim data set from 1979 to 2011. Atmos. Chem. Phys., 14, 913-937, https://doi.org/10.5194/acp-14-913-2014.

Stein, A. F., R. R. Draxler, G. D. Rolph, B. J. B. Stunder, M. D. Cohen, and F. Ngan, 2015: NOAA's HYSPLIT atmospheric transport and dispersion modeling system. Bull. Amer. Meteor. Soc., 96, 2059-2077, https://doi.org/10.1175/BAMS-D14-00110.1.

Stevenson, D. S., and Coauthors, 2006: Multimodel ensemble simulations of present-day and near-future tropospheric ozone. J. Geophys. Res., 111, D08301, https://doi.org/10.1029/ 2005JD006338.

Stohl, A., and Coauthors, 2003: Stratosphere-troposphere exchange: A review, and what we have learned from STACCATO. J. Geophys. Res., 108, 8516, https://doi.org/ 10.1029/2002JD002490.

Tarasick, D. W., and Coauthors, 2019: 2019: Quantifying stratosphere-troposphere transport of ozone using balloonborne ozonesondes, radar windprofilers and trajectory models. Atmos. Environ., 198, 496-509, https://doi.org/ 10.1016/j.atmosenv.2018.10.040

Trickl, T., H. Vogelmann, H. Giehl, H.-E. Scheel, M. Sprenger, and A. Stohl, 2014: How stratospheric are deep stratospheric intrusions? Atmos. Chem. Phys., 14, 9941-9961, https://doi.org/ 10.5194/acp-14-9941-2014.

Waugh, D. W., 2005: Impact of potential vorticity intrusions on subtropical upper tropospheric humidity. J. Geophys. Res., 110, D11305, https://doi.org/10.1029/2004JD005664.

Wernli, H., and M. Bourqui, 2002: A Lagrangian "1-year climatology" of (deep) cross-tropopause exchange in the extratropical Northern Hemisphere. J. Geophys. Res., 107, 4021, https://doi.org/10.1029/2001JD000812.

Zimet, T., J. E. Martin, and B. E. Potter, 2007: The influence of an upper-level frontal zone on the Mack Lake Wildfire environment. Meteor. Appl., 14,131-147, https://doi.org/10.1002/met.14. 